\title{
REMAKING MACROECONOMIC POLICY AFTER THE GLOBAL FINANCIAL CRISIS: A BALANCE-SHEET APPROACH *
}

\author{
Christopher Adam \\ Department for International Development and St Cross College, \\ University of Oxford
}

\author{
David Vines \\ Department of Economics and Balliol College, University of Oxford; \\ Centre for Applied Macroeconomic Analysis, Australian National University; and \\ CEPR
}

\author{
15 March 2010
}

Forthcoming in the Oxford Review of Economic Policy

\begin{abstract}
This paper describes the origins of the global financial crisis and how the prevailing New Keynesian macroeconomic orthodoxy failed to anticipate its severity. This failure, we argue, stemmed from an incomplete understanding of the pivotal role of financial institutions in the amplification of the crisis and its transmission to the wider economy. Low global interest rates and a consequent 'search for yield' in the pre-crisis period encouraged financial institutions to build highly leveraged balance sheets which, in turn, generated extremely large asset price movements when a 'small event' - the downturn in the US sub-prime mortgage market -- triggered the crisis. The paper then briefly describes the element of the broadly successful and coordinated macroeconomic policy response to the crisis before turning to the medium term challenges facing policymakers in sustaining global recovery. At the national level, we focus on the resolution of fiscal imbalances which contributed, in part, to the crisis, and which then worsened because of the policy actions which have been taken to deal with it. At the international level, we emphasise the need to rectifying the imbalances between savings and investment in many significant countries. This will require greater coordination of macroeconomic policy across the world's major economies. It will also involve strengthening the role, and the governance, of the International Monetary Fund.
\end{abstract}

\footnotetext{
We are indebted to Christopher Allsopp and Wendy Carlin for their perceptive advice and guidance in response to earlier drafts of this paper. Roger Farmer, Simon Gilchrist, Andrew Graham, David Gruen, Robert Hall, Dieter Helm, Hal Hill, Harrison Hong, Vijay Joshi, Christopher Kent, Warwick McKibbin, Gordon Menzies, Adrian Pagan, Richard Portes, Paul Luk, Andy Stoeckel, Ted Truman and Simon Wren-Lewis have provided many helpful comments. And the authors of the other papers in this volume have helped us with a number of valuable discussions.

Some of the material in this article was first set out in Joshi and Vines (2008). More extensive versions were presented at an NCAER-CEPR Conference on 'India in the G20 - Macroeconomic Policy Coordination, Regulation and Global Governance', held in New Delhi, on 1 June, 2009, and at an ICRIERCEPII-BRUEGEL Conference on 'International Cooperation in Times of Global Crisis: Views from G20 Countries', held in New Delhi, on 14 \& 15 September 2009. That material was developed in a presentation to a Conference on 'The Crash of the Financial System: Bad Luck or Bad Structure' held at University of Technology Sydney on $28^{\text {th }}$ to $30^{\text {th }}$ October 2009, and at seminars at the Australian National University, Queensland University of Technology, and at the Reserve Bank of Australia in October and November 2009.

David Vines's work on this paper was carried out under the auspices of the European Union Framework Seven Research Programme on the Politics and Economics of Global Governance: the European Dimension (PEGGED). His work was undertaken at both the Australian National University and at Oxford University. He thanks both institutions, and Balliol College, Oxford, for support during this period of time
} 


\section{INTRODUCTION}

\subsection{Why we didn't get it then and what we need to do now}

We have just lived through a financial crisis of extraordinary magnitude. It led to the near seizure of financial markets across the world, and has subsequently caused the largest downturn in global economic activity since the Great Depression. Despite this, most macroeconomists and policymakers did not see it coming. Why not? And what should we all do now?

The present paper provides our answer to these two questions. ${ }^{1}$ We proceed in four stages.

Section 2 describes the 'Great Moderation' which preceded the crisis and asks why the macroeconomic theory which went with it - widely known as 'New Keynesian macroeconomics' - failed to alert us to the possibility of crisis. Section 3 examines the two causes of the crisis. First, in the early years of the $21^{\text {st }}$ century global interest rates fell sharply, and then remained substantially below their long run trend for more than three years. Second, in the face of such low interest rates, a 'search for yield' led to a spectacular increase in the leverage of the financial system. The crisis came when, due to this leverage and due to global interconnections, a small shock - to the US housing market - caused a huge crisis - in the entire global financial system.

Section 4 describes the policy responses so far. The crisis could have led to a global economic collapse of the magnitude of the Great Depression. This did not happen. Rather, governments responded to the crisis - through monetary policy and fiscal policy - in ways which have been, in the main, substantial, decisive and coordinated.

But an effective short-run response is only part of the story. In Section 5 we consider the medium term challenges facing policymakers in sustaining global recovery. At the national level, we will need to resolve the fiscal imbalances which contributed to the crisis, and which

\footnotetext{
${ }^{1}$ In writing the paper we have been greatly influenced by Blanchard, et.al (2010) and by Bean (2009). Obstfeld and Rogoff (2009) cover similar ground, but do not range as widely. For a helpful narrative guide to the crisis, see Garnaut and Llewellyn-Smith (2009). Krugman (2009) is also thoughtprovoking.
} 
then worsened because of the policy actions which have been taken to deal with it. At the international level, attention must now centre on rectifying the imbalances between savings and investment in many significant countries, and that will involve coordinating macroeconomic policy across the world's major economies. It will also involve strengthening the role, and the governance, of the International Monetary Fund.

These are big issues, of historic significance. The Great Depression led Keynes to write his General Theory, thereby creating macroeconomics as a basis for national macroeconomic policymaking. The Second World War led - via the Bretton Woods Conference - to the creation of international macroeconomics, and to the birth of the IMF as a forum for the international coordination of macroeconomic policy. ${ }^{2}$ The present global financial crisis will - we think - most likely lead to a major shift in our understanding of the role of finance in macroeconomics, in both theory and in policymaking. Hence the title of this paper.

\subsection{The papers in this Double Issue of OxREP}

This article forms the opening paper in a two-volume double-issue of the Oxford Review of Economic Policy on the macroeconomics of the crisis. Our argument in this paper depends, to a considerable extent, on the arguments presented in the other papers in this collection. ${ }^{3}$ This paper also, to some extent, summarises the contents of those other papers.

The layout of the two volumes is as follows.

Following this introductory paper, Volume One opens with two papers on the global macroeconomic causes of the crisis. The first, by Hamid Faruqee, Alasdair Scott, and Natalia Tamirisa, sets the stage empirically. This is followed by a paper by Andrew Stoeckel and Warwick McKibbin, who use a global simulation model to explore quantitatively both the causes of the crisis and its transmission internationally. Next are two papers on the financial system and the crisis. The first of these, by Xavier Frexias, provides a view as to how this crisis spread through the financial system, and describes how this has influenced the monetary

\footnotetext{
${ }^{2}$ The Bretton Woods conference was held because policymakers wished to run the world economy at full employment after World War II, in contrast to what had happened after World War I. (See Skidelsky, 2000, Vines, 2003, 2008, and House, Corden and Vines, 2008).

${ }^{3}$ We would like to thank the authors of these articles, both for their contribution our project, and for the discussions, and correspondence, which we have had with them as the double-issue took shape.
} 
policy which has been adopted to deal with it. The second, by Alastair Milne, focuses on regulatory failures, and the ways in which, in the future, macro-prudential regulation might overcome these.

Volume Two opens with three papers on the monetary responses to the crisis. Spencer Dale, James Proudman and Peter Westaway discuss the short-run policy response to the crisis by the Bank of England, while Nicoletta Batini and Eugen Tereanu provide a model-based analysis of the behaviour of inflation targeting regimes in the face of the kinds of inflation shocks which were experienced in the run-up to the crisis. The final paper in this set is a short piece by Adam Posen and Arvind Subramanian, in which the authors argue for greater international monetary policy coordination in the control of inflation. The later part of this second volume consists of four papers on the role of fiscal policy in dealing with the crisis. The first two by Max Corden and Willem Buiter respectively examine the role of and limits to fiscal policy during the crisis. The final papers by Simon Wren-Lewis and Ray Barrell and Martin Weale discuss longer term fiscal policy choices. These are choices which, as we have already noted, will determine whether we have learned the right lessons from the crisis.

\section{BEFORE THE CRISIS:}

\section{THE ‘GREAT MODERATION’ AND THE THEORY THAT WENT WITH IT}

The period prior to the crisis became known as 'the great moderation' (Bernanke, 2004) - a time of remarkable macroeconomic stability in advanced economies, in which there was low and stable inflation, and steady if not spectacular growth. It was recognized at the time that this success might have partly resulted from the fact that demand shocks were unusually small and benign and were dominated by favourable global supply shocks. Nevertheless, it appeared that the pursuit of inflation targeting by independent central banks, or the pursuit of similar stability-oriented monetary policies, had successfully anchored inflation. And, in the presence of such low inflation, policy appeared to have become sufficiently flexible as to keep demand closer to full employment, in the face of demand shocks. ${ }^{4}$

The dominant macroeconomic theory underpinning these flexible inflation-targeting regimes was New Keynesian macroeconomics, the sharpest articulation of which is provided by

\footnotetext{
${ }^{4}$ See Bean (2009) for a discussion.
} 
Clarida, Gali and Gertler (1999) and Woodford (2003). ${ }^{5}$ At its simplest, this body of work suggests that the macroeconomy can be analysed using a three equation system consisting of: (i) an IS curve relating expenditures to the interest rate (derived from the behaviour of optimising, forward-looking individuals, who maximise the value of a utility function), (ii) a Phillips curve (which allows for some price rigidity because it has a Calvo setup in which there are forward-looking prices setters whose behaviour is constrained by overlapping contracts), and (iii) a monetary policy-maker who sets the short-term interest rate (whose policy derives either from a Taylor rule, or from the optimisation of an arbitrary loss function in inflation and output, or from the optimisation of a micro-founded loss function depending on the preferences of the representative consumer). New Keynesian macroeconomics shows how policymakers can stabilse inflation in the face of supply-side shocks, and subject to that being achieved, can and should stabilise output in the face of demand shocks. Many applications of the theory came to reflect the self-confidence of policymakers. For example, Kapadia (2005) showed how, after any supply side-shock hits the economy, the more the private sector believed that the inflation target will be achieved, the easier it would be for policymakers to achieve it. And there was some hubris. Blanchard (2008) wrote that "the state of macro is good.... The battles of yesteryear...are over, and there has been ... a broad convergence of vision."

An important feature of New Keynesian models concerns how those models treat the financial sector. In these models, financial intermediation is essentially costless, and can provide no impediment to the functioning of the economy. A competitive financial system - the banking system - drives risk premia down to low levels, so that - effectively - all short-term interest rates, including those on private debt, are set by the central bank. In versions of these models containing long-dated assets, the price of these assets is set by an inter-temporal arbitrage condition, so that the return on them is equal to the return which would be earned by holding a succession of short-term assets. As a result, the policy-maker who sets the short-term interest rate effectively sets the long-term interest rate as well. (See Blanchard et al, 2010.) This whole setup is thus silent on how balance-sheet problems of financial intermediaries can lead to very large increases in the risk premium attached to holdings of longer-dated assets. It is therefore silent on how leverage can lead to crisis.

\footnotetext{
${ }^{5}$ See also Allsopp and Vines (2000) and Carlin and Soskice(2005)
} 
We now know that beneath the surface of the great moderation there were forces at work which would undermine its hard-won stability. In this paper we will focus on the financial forces which we have just identified, forces which emanated from the balance-sheet problems of financial intermediaries. Those problems were, in turn, a consequence of the highly leveraged behaviour of the financial intermediaries. Such financial forces were entirely absent from the prevailing New Keynesian paradigm. To paraphrase Donald Rumsfeld: 'we didn't know what we didn't know'.

\section{THE CRISIS}

\subsection{Savings-Investment Imbalances and Low Global Interest Rates}

\section{Preliminary}

To understand why interest rates fell so much we need to go behind the kind of short-run analysis underpinning the IS curve in New Keynesian macroeconomic analysis, in order to examine a longer-run set of economic forces. Of course in a flexible inflation-targeting regime the central bank sets the interest rate in a way which partly depends on the extent to which inflation is away from its target. But if there are no inflation disturbances - as was true in the decade before the crisis - the central bank will set the interest rate at a level at which resources will be fully employed, the so-called 'neutral' rate of interest (see Woodford, 2003 and Wicksell, 1898). At any point in time this neutral rate of interest depends not just on the forces which determine the supply of savings by households but also on the longer term forces which determine the demand for investment. The neutral rate of interest is that interest rate which equates the demand for 'loanable funds' by investors to the supply of these funds by savers. If things change, then the neutral interest rate changes.

A central feature of the period of the great moderation, up to at least 2004, was the high level of ex ante world savings relative to world investment, which led, ex post, to a low level of the neutral interest rate, world wide. (See Bernanke, 2005, and Wolf, 2008) We need to understand why this happened. We also need to understand why these changes were concentrated geographically, with enormous net deficits (an excess of domestic investment over domestic savings) in the US, and to a much lesser extent the UK, Spain and Australia, being offset by net surpluses in Germany, Japan, Middle East oil producers and, most 
importantly, China and the Far East (see Faruquee et al, this volume, Figure 3 and Dooley et al, 2005).

\section{East Asia}

The story begins with East Asian crisis which struck in 1997-98. ${ }^{6}$ The proximate cause of the crisis was a collapse in investment which fell by around 10 percent of GDP across Thailand, Indonesia, Korea and Singapore. The outcome was a conventional Keynesian recession; consumption fell with income as investment fell. ${ }^{7}$. Recovery in much of Asia - notably in Thailand, Korea and Malaysia - came through sharp nominal and real exchange rate depreciation which stimulated rapid export growth which replaced the missing domestic demand and enabled what - in retrospect - was a very rapid recovery from the crisis. China did not devalue at the time of the crisis, but maintained its peg to the dollar. As a result, it underwent a significant period of deflation, starting from 1999 and continuing until the early years of the present decade. But the peg was maintained, locking in the resulting gain in competitiveness which was further enhanced by rapid technological progress, fuelled in part by FDI. So the Chinese real exchange rate also came to be greatly depreciated, leading to a very rapid growth in exports there also.

The distinctive feature of the decade since the East Asian crisis has been the transformation of this export-led-recovery strategy into an export-led-growth strategy. Undervalued exchange rates and rapidly growing exports meant that sustained external demand allowed these economies, and especially China, to solve the development challenge of generating sufficient productive employment to absorb a vast quantity of surplus labour in the agricultural sector.

\footnotetext{
${ }^{6}$ See Corbett and Vines (1999a, 1999b) and Corbett, Irwin and Vines (1999).

${ }^{7}$ The reason for the fall in investment bears some similarity to what has happened in advanced economies during the present crisis. Financial systems in Asia were relatively underdeveloped and, as a result, fragile. Throughout the 'Asian miracle' period of export-led growth leading up to the crisis, investment in export capacity had been had been highly leveraged. And, with the liberalization of these countries' capital markets, much of this borrowing was undertaken abroad. When, starting in Thailand, the growth of exports slowed in 1996-97, firms found themselves unable to cover the interest payments on their outstanding loans (Warr and Vines,2003) Similarly in Korea (Chung and Eichengreen, 2003) and elsewhere in Asia. The result was widespread bankruptcy, which spread into the banking and financial systems, and to subsequent further collapse of investment due to the difficulty of obtaining credit.
} 
A key question is why this strategy was preferred over an alternative which might have relied on building up investment and consumption at home. There are basically four reasons for this. The first is that public policy encouraged a build up reserves to guard against future crises (Eichengreen, 2004, Portes, 2009) - a public-sector strategy of self-insurance against future crises. This explains what happened for the first few years, but it is not a satisfactory mediumrun story. Second, high gross savings rates in Asia, particularly in China, have, to a large extent, reflected slow-changing structural and demographic characteristics, including relatively weak social security and pension systems (see for example, Prasad, 2009 and Wei and Zhang, 2009). Third, with the important exception of China, domestic investment rates amongst the Asian crisis countries remain substantially below their pre-crisis levels even a decade after the crisis, partly because of underdeveloped financial markets (see Caballero et.al, 2008, and Mendoza et al, 2007). Finally-and most importantly -the 'Bretton Woods II' argument (see Dooley et al, 2004a, 2004b) suggests that several major developing and emerging market countries, in particular China, deliberately pursued an export-led growth strategy because one can keep rates of return high - and so guard against diminishing returns - by relying on rapidly growing exports. Doing this enables one to sell into existing global markets for products, using best-practice global technology -- partly introduced through FDI -without having to build domestic markets. ${ }^{8}$

\section{Other countries with high savings rates}

Other major economies, notably Japan and Germany have followed essentially the same export-led growth strategy for almost 60 years. In Germany, in particular, the surplus (as a percent of world GDP) increased very rapidly from 2000 as the burden of unification faded. Commodity producers, especially the oil-rich economies of the world, have also contributed decisively to net saving and have typically invested these surpluses in the US. For these economies the savings patterns partly reflect an efficient savings response to a temporary increase in the price of exhaustible natural resources and partly the same impetus towards reserve accumulation as self-insurance against future crises.

\footnotetext{
${ }^{8}$ Aizenman et al (2004) amongst others have shown that contrary to the textbook model of capital allocation, the growth record of developing countries that are net exporters of savings is consistently superior to those that are net importers.
} 
The strategies in Asia, and elsewhere - some the outcomes of deliberate policy strategies, but others the outcome of much more complicated incentives and constraints on private sector agents and governments - were an important part of the reason as to why global interest rates fell decisively at the beginning of this decade. But only a part.

Between 1998 and 2000 the fall in Asian net investment had been matched by a rise in investment in the US as a result of the dot-com boom, ensuring that global output growth remained high, and enabling East Asian economies to recover from their financial crisis by means of export-led growth. But when the dot-com bubble burst around the end of 2000, US investment expenditure fell sharply. As a result, the IS curve in the US shifted inwards to the left. To counteract this collapse in investment, aggregate demand was maintained in the US by means of low interest rates, and by an emerging US budget deficit. (Between 2001 and 2003 the nominal rate fell from $6.5 \%$ to $1.2 \%$ (and the ex post real short-run interest rate fell from around $3 \%$ per annum to $-1 \%$ ). ${ }^{9}$ As Faruquee et al show (this volume, Figure 1), such a movement meant that long-term real interest rates went from above to decisively below their long-run trend. Over the same period, the US structural budget balance shifted from a surplus of around $2.1 \%$ of GDP to a deficit of $2.5 \%$ of GDP.

The sharp cut in nominal interest rates in the US from mid- 2001 happened because the sharp decline in investment after the dot-com crash led to a fall in the 'neutral' real interest rate. This touches a fundamental point about the fact that - after the dotcom crash - an underlying weakness in investment in the US was revealed. This is a vibrant economy at the top end of the technology spectrum, but lower down there is a lurking low-level-of-productivity difficulty (witness what has subsequently happened to the US car industry). The Fed's actions effected the necessary adjustment in the real rate through changes in the interest rates, in a manner consistent with maintaining low inflation. This reaction in monetary policy was a response to the fall in US investment relative to US savings, a response which has become known as the 'Greenspan put'. ${ }^{10}$ There was also a significant fiscal expansion in the US at this

\footnotetext{
${ }^{9} \operatorname{IMF}(2009)$

${ }^{10}$ This name reflects the fact thatmarkets came to anticipate monetary policy responses to negative shocks during the Greenspan era. Over this period the Fed had consistently responded to crises in
} 
time, driven by considerations unrelated to the management of aggregate demand ${ }^{11}$, something which meant that the interest rate cut was less than it would otherwise have needed to be. Such a response was very different in kind from that which had happened a few years earlier in East Asia, where recovery had been sought by means of an export-led recovery, facilitated by exchange-rate depreciation.

The downturn in the US, and the cut in interest rates in the US to which it led, was expected by many to lead to a significant depreciation of the dollar. ${ }^{12}$ This did not happen - although the dollar dif weaken gradually between 2001 and 2007. The anticipated exchange rate adjustment did not occur in part because the cut in US rates was accompanied by cuts in interest rates in the UK, the Euro area, and elsewhere, thereby sustaining demand in other advanced countries, and preventing the dollar from falling against the pound and the Euro. The other reason was the explicit maintenance of undervalued exchange rates in East Asia which prevented the dollar from falling against the currencies of those countries, and ensured that demand growth was transmitted to East Asia. In Korea, Thailand, Indonesia, .interest rates fell in line with the fall in the US, but investment remained subdued. In China, by contrast, investment did grow rapidly and so interest rates were reduced by less than the reduction in the US, thus damping - for a while - the effect of this change in US monetary conditions on domestic demand.

\section{Before the crisis: summarising global outcomes in a two-country model}

The central features of this outcome can be illustrated using a simple two-country model. Imagine a world consisting of two countries, which we shall label the US, and China, where the former represents the major deficit economies and the latter we can think of as being an amalgam of China, the rest of East Asia, and other surplus countries. Let inflation be under control - as it was in the early 2000 s - so that this is a sticky-price, flexible-output, world. We assume perfect capital mobility between the two countries, represented for simplicity by UIP and, also for simplicity, we abstract from expectations.

financial markets (from the 1987 stock market crisis, through the Mexican and Asian crises, the LTCM debacle and the first Gulf War) by providing liquidity to markets, effectively putting a floor beneath asset prices and so limiting downside risks: hence the analogy with a 'put' option in which the option-holder acquires the right to sell at a pre-agreed price if prices drop.

${ }^{11}$ The Bush Administration's prosecution of war in Iraq and its large-scale tax cutting agenda were the most obvious of these.

${ }^{12}$ See Obstfeld and Rogoff (2002) 
We now introduce the targets and instruments of the two countries. The two targets are the full employment of resources in both countries, and the two instruments are the world interest rate and the real exchange rate between China and the US. The assignment of instruments is crucial. We let policy in China set the (real) exchange-rate between the US and China, and let monetary policy in the US set the world interest rate, where the latter is set to deliver full employment in the US. Monetary policy in the China is set to deliver full employment there.

It is easy to demonstrate the following result. Suppose that we start with current-account balance between the two countries and full employment of resources in both countries and consider a reduction in aggregate demand in China. (This is the savings-investment imbalance at the time of the Asian crisis which we discussed above.) We then solve for the targets-andinstruments solution to the model which ensures that, after this shock, resources remain fully employed in both the US and China. The solution is one which the real value of the currency in China must depreciate - to suck in demand and keep activity high in that region - and world interest rates must fall - so as to ensure full employment in the US. This simply summarizes much of the discussion above.

It is also possible to prove an additional simple result. Let us impose a second shock on top of the first one - namely a large improvement in productivity in China, of a kind which shifts world demand towards its goods. (This could be thought of as the cumulative result of large volumes of FDI into China and elsewhere in Asia, enabling China to increase its share of word trade by producing and exporting goods which it previously could not produce.) Let us also suppose that --for whatever reason - policymakers in China attempt to keep the real exchange rate at the depreciated level which was desirable when only the first shock had happened. Two things then follow.

(i) There would be over-full employment and inflationary pressures in China, unless this was controlled by some method ${ }^{13}$, because so much of the world's demand for traded goods had shifted to China.

\footnotetext{
${ }^{13}$ In fact, Chinese policymakers appear to have relied upon increasing the savings rate out of the profits of state-owned enterprises.
} 
(ii) Interest rates would need to be even lower in the US to ensure that full employment in the US was maintained.

We can think of this setup as one in which the Federal Reserve in the US acts as a Stackleberg follower, i.e. it sets monetary policy so as to achieve the desired outcome in the US, conditional on what happens in the rest of the world. This is an application of Bean's idea that, in the macroeconomic policy-making regime of the late 1990s in the UK, the Bank of England acted as Stackleberg follower, setting monetary policy so as to deliver the inflation target, conditional on the fiscal policy being pursued by the Treasury. (Bean, 1998) ${ }^{14}$

Bean's idea was that in the UK the Treasury acts a Stackleberg leader when it sets fiscal policy - and, in particular, that because of this, the Treasury would not be tempted to overexpand the economy, since it would know that if it did the monetary authority would just raise interest rates and activity would not actually increase. Of course, in reality our 'China' of the model cannot act as a unique Stackleberg leader in our setup, since there are - in fact - many players in the rest of the world. But it has sometimes looked as if the Chinese authorities acted as they did, setting real exchange rates so low as a means to obtain full employment of resources, precisely because they knew that the US Federal Reserve would (in partnership with US fiscal authorities) act as a Stackleberg follower and ensure that demand outside China grew rapidly enough. In other words, given inadequate demand in the US and the constraint of Chinese exchange rate policy, the US was left with no option (if it wanted to keep unemployment down) to the strategy of low interest rates which it adopted.

\section{Could the Fed have behaved differently?}

In retrospect, the exercise of US monetary policy in this way had profound implications for the evolution of the global economy throughout the remainder of the decade. Was there an alternative strategy?

John Taylor has argued ${ }^{15}$ that US interest rates need not have fallen as much as they did, and could have been raised again much more rapidly than they were, if the US policy-makers had

\footnotetext{
${ }^{14}$ This Stackleberg setup is discussed in detail by Allsopp and Vines (2005), and Kirsanova Stehn and Vines (2005)

${ }^{15}$ See Taylor (2008) and the discussion of his argument in Bean (2009).
} 
followed something much more like a Taylor rule when they set interest rates. ${ }^{16}$ However, a recommendation that policy follow a given, unchanging, Taylor rule requires one to assume that the neutral rate of interest is constant. But, as noted above, the period from $2001-2004$ was a period when the neutral rate of interest fell significantly. Following the higher interest rate suggested by a Taylor rule would have created a recession, possibly leading to deflation and would certainly have ended the great moderation. The cut in interest rates was precisely engineered to avoid this recession and to enable the great moderation to continue. ${ }^{17}$

Perhaps a contractionary squeeze would have been desirable. But it is also hard to see how, with inflation under control, Greenspan could have brought this about. Furthermore, any idea that interest rates could have been raised ignores the political environment of the time. It is inconceivable that Greenspan could have announced that 'this is the recession you need to have', just after September $11^{\text {th }}, 2001$. And it is also hard to see how, against a background of the war in Iraq, he could have done this at any time, at least up until the end of 2004

An obvious alternative adjustment path in which growth could have been maintained would have been one in which the dollar fell along with the reduction in US interest rates. If this had happened, the fall in US interest rates would not have needed to be so large, since some of the recovery from the dot-com crash would have happened by means of an improving currentaccount position. The US current account deficit was, at the time, around four percent of GDP, a level which was, until then, historically unprecedented. A reduction of a large proportion of this external deficit, brought about by means of a depreciation of the dollar, would have compensated for the fall in investment.

But - for the reasons we noted above - the dollar did not depreciate sufficiently at this time. The pursuit of undervalued exchange rates in East Asia - to ensure a rapid growth of exports meant that US interest rates had to fall by a very great deal, and be maintained at very low levels for three years, in order to ensure that the growth of demand in the US was rapid enough to ensure full utilisation of resources. From this, global current-account imbalances emerged, with surpluses, principally in East Asia but also amongst other fast-growing

\footnotetext{
${ }^{16}$ Ted Truman maintains something similar in his comments on an earlier version of this paper (See Truman, 2009, and Vines, 2009). We are grateful to Truman for a useful discussion of this issue at the ICRIER-CEPII-Bruegel conference in New Delhi in September 2009.

${ }^{17}$ Obstfeld and Rogoff (2009) make the same point.
} 
emerging market economies and commodity exporters, counterbalanced by large and growing current account deficits in the US, the UK, Australia, Spain and Ireland. (See Blanchard and Milesi Ferretti, 2009.) Taking on the obligations of 'spender of last resort' - which caused US interest rates to remain low for longer than otherwise might have been the case - had very significant consequences for the US, and for the global economy

\subsection{Systemic Balance-Sheet Risks created by Low Interest Rates}

To understand the effects of these lower interest rates on the world economy we need to go behind the New Keynesian macroeconomics in a second, different, kind if way. We need to understand how well the financial markets in the US, and elsewhere, allocated the 'loanable funds' from savers to investors, at a time when interest rates were very low. The answer was - not very well. As we shall see, the balance sheets of financial institutions played a role in this.

\subsubsection{A benchmark model without leverage}

We start with a simple benchmark 'model' of the financial system. Consider a long-dated asset, such as an equity claim (or for that matter, a house), paying a real dividend $x$ which is expected to grow at a constant rate $g$. Discounting this revenue stream by $(r+\delta)$, where $r$ is the real interest rate and the risk premium is $\delta$, allows us to obtain a price for that asset, $p$, as $p=\frac{x}{r+\delta-g}$

Clearly, a large reduction in interest rates, $r$, will inevitably lead to a correspondingly large increase in the price of financial assets, especially if we begin from a position where $r+\delta$ is not much bigger than $g$. Such an increase in the prices of these assets will increase household wealth and will thereby lead to an increase in consumer spending. An increase in asset prices will also encourage investors to borrow money and invest in these assets, since their price will exceed their replacement cost. (This is just Tobin's q theory of investment.)

Simple as it is, this formula brings out a number of points relevant to this discussion. The first is that asset prices are potentially very volatile, since even small changes in either $r$ or $g$ can 
give rise to a large change in $1 /(\mathrm{r}+\delta-\mathrm{g})$. For reasons we have discussed, real interest rates were low from 2002 onwards, and through the great moderation growth rates were relatively high. This suggests, according to this model, that asset prices should have been very high. Indeed, if growth is higher than real interest rates by an amount approaching the risk premium, this model suggests that asset prices should have tended towards infinity!

The second is the importance of the risk premium. With high growth and low real interest rates, asset prices are held down by the perception of risk. But the risk premium is not a datum. One of the features of the situation was that risk premia appeared to fall over time reflecting confidence in the continuation of the great moderation. This model implies that this, too, would cause an upward drift in asset prices.

McKibbin and Vines (2003) perform a number of simulations, using a model which includes the above asset pricing formula, to analyse the effects of the dot com collapse in 2001-2002. In these simulations, interest rates were cut, causing a very large increase in the prices of assets - including housing - which was part of the transmission mechanism by which lower interest rates stimulated the economy after the collapse. Then - in these simulations - interest rates gradually rose again as risk premia fell, investment picked up and the recovery got underway. And asset prices gradually subsided, causing consumption demand to gradually fall to make room for the increased investment. It seemed very clear what might happen going forward for the rest of the decade.

This analysis turns out to have been a spectacularly inadequate prediction of what would happen. Instead, from 2005 onwards there was a rise in interest rates, and a rise in perceived risk, along with a changed perception of likely future growth (in the downward direction). The resulting fall in asset prices was not gradual by dramatic. We now set out to understand how and why this happened.

\subsubsection{Collateral and the gradual rise in asset prices}

The first qualification to make is that, in practice, asset prices are unlikely to immediately jump up following a fall in interest rates in the way implied by the benchmark formula. This was especially true in the case of house prices. In fact, house price growth was gradual in the US when interest rates fell (see Faruquee et al this issue). 
There are several possible reasons for this. One is that expected future interest rates may be slow to adjust to the fall in current short-run rates. Another reason is that house price rises are limited by collateral constraints. As the demand for mortgage-backed securities rose, and so the interest rate on mortgages fell, households increased their demand for them, and used part of their increased borrowing to buy more housing and push up the price of houses. With the growth of sub-prime mortgages, further households entered the mortgage market, enabling the price of housing to be pushed up even further. But the demanders of mortgages are collateral constrained: what can be borrowed for the purchase of housing depends on the prices of the houses which people already own. This is because, for most households, an already-owned house is all that can be used as collateral for a mortgage. But the prices of these houses, in turn, depend on what can be borrowed. This circularity means that the increase in prices cannot be immediate, but must be gradual, happening alongside the increases in collateral. ${ }^{18}$ And, of course, a continuing rise in house prices meant that the 'own rate of return' on housing assets rose, encouraging yet more borrowing amongst those who were not collateral constrained. Hong (2009) gives an additional account of why there was such 'momentum' in house prices, based on an analysis of trend chasing. ${ }^{19}$

There were two consequences of this gradual increase in the price of housing. First, consumption increased, because those consumers who increased their mortgages used the money so obtained not just to buy houses but also to increase consumption of other goods and services. Second investment increased, and, in particular, investment in housing increased: there was a construction boom. The route from lower interest rates to higher aggregate demand was a more complex one than in the benchmark model. But the effect was the same; lower interest rates led to higher expenditures.

Nevertheless one might expect that, when interest rates rose again from late 2004 onwards, this whole process would go smoothly into reverse as the recovery got under way.

\footnotetext{
${ }^{18}$ See Kiyataki and Moore (1997) and Miller and Stiglitz (2009) for an analysis of this process.

${ }^{19}$ Hong imagines that there is a 'dose' of news about a stock at time $t$ and none thereafter. 'Newswatchers' cause the price to move at $t$ but, due to a lack of full information, do not move it far enough. Trend chasers who get in at time $\mathrm{t}+1$ make money, and accelerate the price increase, but also set off another round of such 'momentum buying'. Later trend chasers get in at a price above long run equilibrium value and push price further away from fundamentals. The key insight is that the trades of early trend chasers inflict an externality on late trend chasers, who cannot tell whether the price move which they observe is due to new news or earlier trend chasing. Trend chasing is nonetheless on average profitable in this setup, because of gradual information diffusion.
} 
Specifically, the analysis suggests that, as short term interest rates rose from the end of 2004 onwards, the price of houses would fall again. One might then have expected consumption to fall. One might have also expected that it would become harder for people to get hold of a mortgage, for demand for houses to fall further, and for this to lead to a fall in housing construction. And there would also be a fall in other investment as a result of the general fall in consumption. Nevertheless, from reading the above one might expect a rise of interest rates to be able to satisfactorily control the outcome, even if the process was somewhat more complex than that identified in the benchmark model.

But something more remarkable than this was under way.

\subsubsection{The 'search for yield' and Highly Leveraged Financial Institutions (HLFIs)}

What happened, during the period of low interest rates, was not confined to the housing market. Many investors engaged in a 'search for yield' by substantially increasing leverage, (i.e. by borrowing money and investing those borrowings alongside their own capital). Such investors took their own capital, or shareholders funds, and supplemented it with short-term borrowing from elsewhere at low interest rates, and then invested these funds in longer term assets paying a higher rate of return. This increased their expected return on their capital, but of course it made that return much more risky.

An example of what can be achieved by leverage is the following. Imagine an investor with $\$ 100$ in capital. Suppose that, if this was invested long-term, it would earn $\$ 3$, or 3 percent. Suppose that, at the same time, the investor borrowed $\$ 900$ short term, at an interest rate of say 2.5 percent, and then invested the overall sum of $\$ 1000$ in long dated securities having a return of $3 \%$. Then the net earnings of the portfolio, after paying the interest due on the shortterm borrowing, would rise from $\$ 3$ to $0.03 \times 100+(0.03-0.025) \times \$ 900=\$ 7.50$. Leverage would have raised the fund manager's return from 3 percent to 7.5 percent.

To see exactly why leverage increases the risk faced by investors at the same time as it increases their prospective return, consider what happens to the above portfolio when the

price of long-dated assets falls by 1 percent. This would mean that the value of the investor's portfolio would fall from $\$ 1000$ to $\$ 990$. As a simple consequence of double-entry bookkeeping, the value of the liabilities on the portfolio must fall one-for-one with the value 
of its assets, in this case to $\$ 990$. But one part of the portfolio's liability structure is unchanged - the value of the outstanding loans which the portfolio manager has incurred, as a result of the borrowing used to fund the long-term investment. This borrowing remains unchanged, at $\$ 900$. The other component of liabilities -- the value of the portfolio to those who originally invested in it -- must take up the slack, falling by $\$ 10$ to $\$ 90$. Thus a 1 percent fall in the value of the long-term assets held by the portfolio will cause a 10 percent fall in the balance-sheet value of the assets of the portfolio. A leverage ratio of 10 (i.e. a ratio of assets invested to own-capital of 10) has increased the proportionate variation in the balance-sheet value of the portfolio by a factor of 10

Leverage not only provides opportunities for what we may describe as 'final investors' wealth holders like those described above. It also enables 'financial intermediaries' - i.e. financial institutions - to increase their yield when they invested on their own account. In the past decade, leverage ratios substantially above ten have been common for investment banks, and for other financial institutions. ${ }^{20}$ We refer to such institutions as 'highly leveraged financial institutions' or 'HLFIs'. One can think of HLFIs as trading off risk and return pursuing the higher return which leverage offered, subject to this return not being too risky. ${ }^{21}$

Of course there is always a search for yield, subject to the constraint of the returns not becoming too risky. But this search is particularly important when interest rates fall, for wealth holders who are liquidity constrained and whose expenditures thus depend on income. These individuals, or institutions, rely on the income from their wealth that would come from a 'normal' return on the assets which they hold. When market yields fall, these investors find themselves in cash-flow difficulties, particularly if their expenditure requirements are difficult to adjust. It is tempting to obtain higher yield by 'leveraging'. Of course, this would be more risky, but the diversification of assets across different classes might lead the investor to think that this risk can be offset effectively. ${ }^{22}$

\footnotetext{
${ }^{20}$ Ferguson (2008), describes how the leverage of Long Term Capital Management (LTCM) rose from around 19 (its 'target rate') in August 1997 to over 30 by June 1998. By August 1998 on the eve of its collapse and bailout, LTCM's leverage ratio was 42 . Turner (2009) shows how by early 2008, leverage ratios amongst a number of major global investment banks had reached similar levels. ${ }^{21}$. Shin (2008) suggests that one can think of the business model of such an HLFI as being a 'value at risk' model, one in which it maximizes leverage, subject to the constraint that it is not likely to lose its capital more than x percent of the time.

${ }^{22}$ Of course if final investors in the economy are engaged in a search for yield, then there will be a great opportunity for HLFIs to expand, in that final investors will want to own a share in the profits which HLFIs create; this will tend to increase the value of the equity of HLFIs.
} 
Low interest rates, the search for yield, and leverage together greatly expanded the demand for long-dated assets, thereby raising their price, creating incentives for the production of such assets. One way of doing this was to encourage people to increase the size of their mortgages on their existing houses. Another way was to encourage people who might not otherwise have been able to borrow ('sub-prime borrowers') to obtain a mortgage and buy a house. In both cases, securitization converted this growth in mortgage debt into an increased supply of tradable long-dated assets, so-called 'asset-backed securities' (see Milne, this volume). But there were many other forms of long-dated asset-backed securities that HLFIs purchased, including corporate equity. All of this activity - in augmenting the rise in house prices and in causing the prices of other long dated assets to rise - added to perceived wealth and so stimulated consumption and investment, well beyond the effects coming from the direct effect of rising house prices alone.

The Asian crisis had given a strong warning that excessive leverage could be highly risky. But the growth of algorithmic risk models in finance led investors, rating agencies, and regulators to believe that such risks could be controlled, or avoided, by diversification. Economic policy makers appear to have believed that this whole process could be gently reversed as the recovery got under way, and interest rates rose. It seemed plausible that the reduced demand for long dated assets by HLFIs in these circumstances would reduce - or at least slow the increase - in the price of houses and of other long dated assets, reducing perceived wealth and consumption, and also leading to lower investment. Thus it appeared that a rise of interest rates would be able to satisfactorily control the outcome, even though the process was considerably more complex than that identified in the benchmark model.

Instead, the attempt to manage the economy in this conventional manner led not to gradual retreat but to sudden collapse of the entire financial system.

\subsection{The Process of Collapse}

There have been many approaches to this 'how can a small shock lead to a large crash' question. The paper in this volume by Milne reviews a number of these approaches. In what follows we concentrate on one particular answer to this question. As elsewhere in this paper, we want to show how a simple model can help provide insight. Our approach will suggest that 
a high degree of leveraging in the financial sector may mean that there is a very large negative overshoot of financial asset prices in response to a small initial shock to financial markets, something which we will then trace through as having a severe impact on the rest of the economy.

\subsubsection{The Trigger: pressure on the investors in longer term assets}

As the global recovery got underway, mid-decade, the leveraged returns from holding long term assets came under pressure from rising short-term interest rates. This happened for three reasons. First interest rates of 1 percent (the US Federal Funds rate in early 2004) are very low by any measure, so that it was to be expected that they would rise back towards more normal levels.

Second, in many countries house prices went on rising even after interest rates began to rise. This happened in the US until 2006, and in the UK until 2008. As noted above, the rise in house prices coming from the reduction in interest rates from 2002 onwards was gradual rather than immediate. The resulting momentum meant that demand for housing remained high even after interest rates began to rise. ${ }^{23}$ This made the task of damping the economy by higher interest rates more difficult than simple New Keynesian macroeconomics would suggest. It was part of the reason for a need for a very sharp increase in interest rates from 2005 onwards.

Third, developments elsewhere in the global economy, most notably amongst emerging market economies, created another, different reason for monetary tightness. For a period, inflationary pressures did not build in the advanced world. This was partly because of the import of goods from China which became steadily cheaper and partly because of the initial success by Asian countries in sterilizing the loose monetary policy entailed by their pegged exchange rate regimes. Despite attempts, at least in China, to use capital controls to counteract the effects of US monetary policy which became too easy for them, the logic of the 'impossible trinity' began to assert itself. It came to be less and less easy both to maintain an undervalued exchange rate and to use a tight monetary policy to control the effects of this on aggregate demand. From 2007, there was a build up of inflationary pressure around the world,

\footnotetext{
${ }^{23}$ Furthermore, the providers of mortgages kept 'starter-rates' low and loan-to-value rates high, relying also on the anticipation of rising house prices, which would mean that borrowers could draw on expected capital gains to justify paying higher rates on a mortgage a year or two after it began.
} 
and by early 2008, global inflation pressures demanded that interest rates be raised.

Returns from holding longer term assets came under pressure for an additional reason. The returns to the asset holders from the underlying real investments also came to look less attractive than they had at the end of the 1990s. As noted above, the dot-com boom had ushered in a belief of a much deeper transformation of the US economy and of US productivity growth than turned out to be the case. Transformation certainly had occurred at the high tech end of the economy, but with the dot com collapse it quickly became clear that this productivity revolution had not run as deep as had been thought. It no longer appeared likely that long-run productivity growth, and hence long-run returns, would be as large as had been imagined.

\subsubsection{The Financial Multiplier: Modeling the Overshooting of Asset Prices}

We proceed by means of the numerical example introduced in Section 3.2.3. Suppose - as there - that that the value of the HLFI's portfolio falls by $1 \%$ from $\$ 1000$ to $\$ 990$. This initial effect will be magnified by a 'financial multiplier' process. Recall that the initial leverage ratio was 10 ( $\$ 1000$ in the total value of investment divided by $\$ 100$ capital). We have already noted that a fall in the value of long-term assets from $\$ 1000$ to $\$ 990$ will cause the value of capital to fall from $\$ 100$ to $\$ 90$. This means that the leverage ratio actually rises from 10 to 11 . If we suppose that the initial leverage ratio of 10 really is a maximum, then the HLFI will be required to contract its balance sheet by selling additional long dated assets - and reducing its borrowing. It will need to do this to enable its investments to fall in line with fall in the value of its capital. To do this in such a way as to bring its leverage ratio back to 10 requires the HLFI to sell further $\$ 90$ of assets. If such a process happens to any one HLFI on its own - facing a fixed price of financial assets - then the outcome would not be remarkable.

But if this process is macroeconomic - that is to say the HLFI is a representative institution then the problem is serious, since the sale of a further $\$ 90$ in assets will force down the price of these assets further. That will cause further contraction in the value of the HLFI's balance sheets, further sales of assets further falls in asset prices, etc, etc. In other words, a 'financial multiplier' process will come into play, and, clearly, if the leverage ratio is greater than unity there is a risk that this multiplier is explosive, as a given fall in asset prices will cause a more than proportional fall in asset sales, prompting a further fall in prices, which is proportionally 
more than the original fall. Whether this happens clearly depends on whether there is anyone else to take up the supply of long dated assets released onto the market as the representative HLFI attempts - in this example - to bring its leverage ratio back to the (assumed maximum) value of 10 . The question then is by how much this asset sale will drive down the price. This depends on the price elasticity of demand of the other holders of long-dated securities.

If the general public will absorb a large quantity of risky assets without much fall in price i.e. if there are many final investors like Warren Buffett - then the system will be stable in the face of the shock which we have described. ${ }^{24}$

On the other hand, if there are no others besides HLFIs who might hold these assets, then the price will fall a lot, because each fall in price will cause HLFIs to dump more and more securities on the market, so as to maintain its preferred leverage ratio. In reality in the past two years, the crisis revealed that the holdings of securitized assets - which (to ensure diversification of risk) were supposed to be distributed widely beyond the banking system had in fact largely remained either within the banking system, or in off-balance-sheet financial vehicles which were still ultimately part of the banking system (Bean, 2009 and Frexias, this issue). This suggests that the demand by the non-HLFI public for long-dated financial assets may have been quite inelastic. ${ }^{25}$

In the limit in which the HLFIs are the only holders of long dated securities, the outcome depends on how far the price of these long-dated securities has to fall, to ensure that supply of leverage increases enough (i.e. the leverage ratio increases enough) to create a floor under the price of these assets. More precisely, in this case the extent of the fall in price depends on how

\footnotetext{
${ }^{24}$ Our understanding of the way in the financial multiplier is likely to induce large fluctuations in financial asset prices owes much to Paul Krugman's note on the 'international financial multiplier'. (Krugman, 2008). Krugman elegantly formalises the multiplier mechanism described here. But he downplays the possibility of very large fluctuations in the price of financial assets by assuming that the demand for risky assets by investors other than HLFIs is highly elastic, in the way we have just supposed in this paragraph.

${ }^{25}$ One reason for this may have been that many of the securitized assets were very complex. The seller has superior information about the assets then the buyer, and they have an incentive to sell the lowestquality assets to the buyer, as in the classic lemon case, which, of course, makes these assets less attractive to the non-HLFI general public. This problem was, of course, exacerbated when the general public's risk aversion increased.
} 
elastic the 'leverage supply function' is to the increase in the rate of return which holders of long-dated securities expect to earn on these assets. ${ }^{26}$

To continue with our example from above, we go on supposing that the fall in the value of long-dated assets from $\$ 1000$ to $\$ 990$ represents the fall in the long run value of these assets. As HLFIs offload these assets, so as to prevent their leverage ratio from rising above its desired level, the value of these assets will go on falling: $\$ 990, \$ 980, \$ 970 \ldots$ But as the price of financial assets falls, there will be an increase in the prospective returns to holders of these assets, assuming that the value of these assets will, eventually, return to their long run level of \$990. This will lead HLFIs to increase their desired leverage ratio. The further the price falls the more this ratio will go on rising, because the larger is the fall in price, the larger are the prospective returns which the holders of these assets expect to earn by holding onto them. Consider what happens in our example when the value of long dated assets falls to $\$ 950$. At this point the value of invested capital will have fallen to 50, and the leverage ratio will have risen to $950 / 50$, i.e. all the way to 19 . Let us suppose that, at this point, the capital gain which they HLFIs expect to earn, as the assets rise in value back to their long-run fundamental value of $\$ 990$, is large enough to induce them to increase their desired leverage ratio to 19 . At that point the value of the long dated securities will stop falling, because investors will be prepared to hold them.

After this overshooting, how will the economy get back to it long run equilibrium? Only by the financial sector building up its capital again, to make up for the capital that it lost when the value of its long dated financial assets fell. When the value of the HLFI's assets has returned to $\$ 990$, the value of its capital will have returned to $\$ 90$. Suppose that when equilibrium has returned the desired leverage ratio also returns to 10 . To support asset holdings of $\$ 990$ with a leverage ratio of 10 , the HLFI will have needed to build up an extra $\$ 9$ in capital. To do this will require that there be a period of time, between the short-run and the long run, during which the gap between the return on long dated assets is larger than it is

\footnotetext{
${ }^{26}$ This approach to showing how there can be very large fluctuations in financial asset prices owes much to the work on the 'financial accelerator' started by Bernanke, Gertler and Gilchrist (1999). That original paper supposes that 'final investors' - i.e. firms and households - are collateral constrained, like the households described in Section 3.2.2 above. In our view the crucial move in this literature came in the papers by Gertler and Karadi (2009), Gertler and Kiyataki (2009), and Gilchrist et al (2009), which make the collateral constraint apply to the financial sector, rather than to final investors. In those papers such a constraint determines how much leverage the financial sector provides. We are grateful to Simon Gilchrist for a helpful discussion of this matter.
} 
in long-run equilibrium - so that HLFIs can build up capital again. ${ }^{27}$ The longer this period of time lasts, of course, the larger the excess of returns which are expected to be earned by holding long dated assets - and so the less they need to fall in price to satisfy investors. If the expectations of assets holders about their future returns are assumed to be model-consistent, then the period that this adjustment process will last, and the point to which asset prices initially overshoot below their long run level, depends on the workings of the whole of the macroeconomic system. ${ }^{28}$

Our macroeconomic model of the crisis is a simple model, stripped to its essentials. But it enables us to see how financial asset prices can overshoot, and how the way in which this happens is interconnected with the behaviour of leverage. It also enable us to see immediately - that the overshoot of financial asset prices will be moderated if other new players, e.g. the government or the central bank (or indeed foreigners), supply extra leverage.

\subsubsection{The Macroeconomic Effects of Asset-Price Overshooting}

The process by which such overshooting in asset prices has an effect on the wider macroeconomy has been simulated by Gertler and Karadi (2009), Gertler and Kiyataki (2009), and Gilchrist et al (2009). We have found simulations of those large DSGE models somewhat difficult to interpret. It is possible, however, to pin down what is going on in these full-model simulations by using a simple stripped-down version of such a setup. (See Luk and Vines, 2010a).

What happens is the following. The three models described above use a particular equation describing the supply of leverage as a function of the short-long risk premium. Using that equation the model then solves for both (i) the endogenous risk premium (between the yield on long-term, risky, financial assets and that on short-term, safe, assets), and (ii) the leverage ratio, as part of the overall macroeconomic response to the shocks applied to the economy. Those responses in turn depend on the whole of the rest of the model. To simulate the crisis

\footnotetext{
${ }^{27}$ As the recovery comes we are already seeing this happening in reality - something which is immensely unpopular politically.

${ }^{28}$ Under the assumption of model-consistent expectations, it can be shown that the model will contain an unstable root. If we assume that the price of long dated assets is a jump variable, and that this price jumps to cancel out the unstable root, then it can be shown that the model will satisfy the BlanchardKahn conditions for stability. (See Luk and Vines, 2010a)
} 
on such a model one takes as inputs the shocks to the underlying fundamentals which are thought to have caused the original downturn in the markets for asset-backed securities. We have described such shocks - a rise in short-term interest rates and a downturn in future growth prospects - in Section 3.3.1. One then simulates the model to investigate whether these shocks to the underlying fundamentals are enough to generate both the very large increase in spreads and the wider macroeconomic impacts that were observed in the crisis.

The wider macroeconomic impacts of the shocks are as follows. The initial collapse in the price of asset-backed securities will cause a reduction in the wealth of those who own the HLFIs, and thus of consumers taken as a whole. Consumption will fall, causing the shock to spread from the financial system into the general macroeconomic system. ${ }^{29}$ Furthermore, the collapse in the value of asset-backed securities will make it more costly for investing firms to raise money, and so investment will fall. In addition, in a world with nominal rigidities, this reduction in consumption and investment will cause a fall in output, i.e. a recession. This will further lower firms' profits, which will further reduce the price of asset backed securities, and so further multiply the downturn. Overall, given a sensible parameterisation of the model, it appears likely that there will be a significant reduction in aggregate demand and output, and so a recession. The recession will, of course, induce the inflation-targeting monetary authority to cut the nominal interest rate and this will dampen the fall in the price of asset backed securities, and thus moderate the recession. But clearly, if the fall in the price of long-dated financial assets is large enough, the monetary authorities may not be able to cut interest rates enough to significantly offset the shocks, before reaching the zero nominal bound.

Clearly the size of the risk premium is jointly determined along with the macroeconomic outcomes. The larger the recession the larger the fall in corporate profits and hence the larger the fall in the price of long dated securities, and so the larger the fall in investment, and so the larger the recession. This shows why a full macroeconomic analysis of these circumstances is necessary. A discussion of the crisis which is confined to a discussion of the financial sector alone will not be satisfactory.

\footnotetext{
${ }^{29}$ In the early days of the crisis there was much discussion of whether, and how, the crisis would spread from Wall Street to Main Street; the outcome in our simple story captures what those discussions were about.
} 
How useful is the approach to the small-shock-large-crash question which we have presented, as compared with alternative approaches? McKibbin and Stoeckel (this volume) also provide a DSGE model-based analysis of the crisis. Their model is similar to that of Christaino, Eichenbaum and Evans (2005) and Smets and Wouters (2003). In these models the short-long risk premium is taken to be exogenous in the way described in Section 3.2.1. McKibbin and Stoeckel take the actual risk premia, as computed from actual data on spreads, and then ask 'would these risk premia, if inputted into our model, be big enough to generate the crisis that we have seen?' In models of this kind there are not just the forward-looking consumers of the New Keynesian model, there are also forward-looking firms who maximise the present discounted value of their expected future profits. A risk premium reduces the present discounted values of these profits and so damps investment. In a revealing set of simulations McKibbin and Stoeckel show that if one assumes that the risk premia are permanent, and fully anticipated, then the simulations produce a crisis which is much more serious than what actually occurred in reality. But if the high spreads are assumed to be temporary, and again fully anticipated, then the simulations produce a crisis which is not bad enough. To reconcile these extreme cases, the authors suggest that people must have initially thought that the crisis was permanent, and then must have changed their minds and decided that it was temporary after all. What led them to change their minds? Arguably, the public policy responses to the crisis captured in the model.

Their analysis provides a very helpful understanding of both of the way in which bad financial outcomes impact on the real economy, and also of the way in which these macroeconomic outcomes are played out in a multi-country world. But what their paper does not do is attempt to give a causal explanation of changing risk premia. It can thus describe, but not really get a handle on, the small-shock-big-crisis question.

The structural approach which we have described above does endogenise the risk premium, by making it depend on the balance sheet of the financial system. This approach is unlikely to be easy to implement empirically, since such implementation will require one to estimate a leverage supply function. ${ }^{30}$ But its virtue is that it connects the explanation of the crisis to the

\footnotetext{
${ }^{30}$ Gilchrist et al (2009) estimate a model of the kind that we are discussing, whose simulation properties depend crucially on the estimated response of leverage to the short-long yield gap. They find that the elasticity of this leverage-supply function is extremely large, so that the price of asset backed securities does not need to fall much, following a negative shock, in order to persuade HLFIs to continue to hold the asset-backed securities. As a result this model will not 'do' overshooting and so
} 
underlying structural characteristics of financial markets. The emergence of risk premia, of a kind which can cause substantial overshooting in the prices of financial assets, and thus have large implications for macroeconomic outcomes, is explained in our story by the balance sheets of financial institutions, rather than simply being imposed on the explanation as an exogenous shock. It follows that regulatory interventions, and the development of macroprudential regulatory initiatives, might be expected to influence these balance sheets and so to cause the outcomes to be different. Macroeconomic models could be used to simulate just how different these outcomes might be. Such developments seem essential as we seek to integrate financial regulation and macroeconomic policy-making.

\subsubsection{Further thoughts on 'financial instability'}

Our macroeconomic model of the crisis is a stable model; one in which the fall in the prices of financial assets is bounded by a supply of leverage, in the way that we have described. It is thus not a story about 'financial instability' in the sense in which macroeconomists might use that term. To macroeconomists the word 'instability' means that one of the eigenvalues of a macroeconomic model is greater than one, so that, following a shock, however small, all variables in the model explode, or implode, without limit. Although many individual institutions collapsed in the course of the current crisis, there was no such unlimited implosion of the system as a whole, just as there was none in the Great Depression. So one would not want a macroeconomic model of the crisis to be an unstable model.

It is also not a story about 'financial instability' in the sense in which this term has been used in analysis of this crisis from a sectoral or microeconomic perspective. This is the perspective adopted by both Milne and Frexias (this issue). From such a perspective, the term 'financial instability' means things like the collapse of financial institutions, or the seizure of the financial system, or what Milne describes as the 'widespread disruption of financial flows'. ${ }^{31}$ Such things have been important in the crisis in addition to the overshooting of financial asset prices upon which we have focussed. Milne identifies three factors which have caused such

will not 'do' the crisis. There are, however, a number of econometric issues which may have seriously biased upwards the elasticity of leverage as estimated in this paper, and thus have seriously biased downwards the potential for asset-price overshooting which it depicts. We are grateful to Adrian Pagan for a discussion of this matter.

${ }^{31}$ There is no 'disruption' of financial flows in our analysis - just an overshooting of asset prices. Nor is the problem 'widespread'; what we have described results from the behaviour of a representative HLFI, rather from the interactions between a number of HLFIs. 
disruption.

The first factor was the collapse of the short term funding through which bank lending was increasingly financed - through unsecured wholesale borrowing, or through the collateralization, or through the issue of asset-backed commercial paper (ABCP) by off balance sheet vehicles. With the collapse of Northern Rock, and especially after the collapse of Lehman Brothers, doubts about liquidity or solvency became widespread. In our simple model we assumed that short term borrowing is available to finance leverage, without limit. After the collapse of Lehman Brothers, this ceased to be true.

The second factor was the extent of counterparty risk. Milne notes that, for securities held in trading books or as investments, it became standard practice to purchase insurance against the possibility of either mark-to-market or cash-flow credit losses. On the face of it, this seemed like prudent housekeeping. It was designed to hedge the risk associated with the holding of longer-dated financial assets, to make the leveraged activity safer, and to lock in profits coming from doing leverage. But this insurance was purchased from a relatively small number of specialized 'monoline' insurance companies, such as AMBAC and MBIA, and from the financial products division of the global insurance giant AIG, often using the traded credit default swap. 'In practice', as Milne says, 'the insurance was illusory because the sellers of this insurance, while claiming large profits from the premiums they received, had far too little capital to honour their promises in the event of a large aggregate shock'

The third factor was 'network interconnectedness' of the kind which can lead to a dominoeffects operating within the financial system; outcomes in which the collapse of one institution can lead to the collapse of other institutions. Recently there has been a considerable interest in modeling these kinds of events and in studying the possibility of highly non-linear responses to external shocks. Such studies focus on the fact that financial systems which appear to be in a satisfactory equilibrium state can collapse after what seems to be a small shock, as a result of such domino effects. Shin (2009) presents such a model, and Haldane (2009) provides an overview of this type of work. Robert May, a biologist, former Chief Scientist for the UK government and former president of the Royal Society, has been important in showing how epidemiological models may be used to study the spread of financial contagion, so as to give insight into the 'small-shock/big-problem' question (May, 2007, 2010). This work is important in showing how a small-shock-to-big-crisis outcome can 
happen within the financial system, without requiring the kinds of macroeconomic feedbacks on which we have concentrated in this paper.

All three of these factors appear to have been at work during the crisis, leading to solvency fears, to a cumulative collapse in liquidity, and so to extreme difficulties in the pricing of risky financial assets. They go well beyond the basic macroeconomic mechanism outlined above. Moreover, there has been a possibility that these separate factors will interact, thereby magnifying the scale of the crisis.

This discussion raises the question of whether the mechanism we have sketched in this paper is sufficient for modeling the macroeconomics of the crisis. Obviously, by failing to incorporate these kinds of disruptions, our framework fails the test at a descriptive level: it clearly lacks the necessary detail. And it also fails the test because, although it can generate (arbitrarily) large asset price volatility, it is firmly embedded within macroeconomic tradition in which models are designed to satisfy local stability conditions (the Blanchard-Kahn conditions). As such, our model is fundamentally unable to deal with the kinds of difficulties that arise when widespread bankruptcy occurs. The relevant question, though, is not whether we can directly replicate specific observed phenomena. Instead the relevant test is (i) whether the model is useful in helping to understand the key macroeconomic mechanisms of the crisis and (ii) whether the model helps us to understand how policy intervention may ameliorate the resulting outcomes. We suggest that the model which we have described, though straightforward, meets this requirement.

\subsection{The International Transmission of the Crisis}

The international transmission of the crisis proceeded through two means. The first is the Keynesian transmission of demand, through reduction in demand for exports. Countries such as Germany and Japan, and China, highly reliant on export demand, saw foreign demand for their exports collapse. Moreover, the collapse of the global financial system caused a disproportionately large effect on trade finance so making this collapse in exports particularly large. Second there has been an international propagation of financial shocks. Many commentators expected this to occur through large and abrupt movements in the US dollar exchange rate as investors moved out of the dollar (see Obstfeld and Rogoff, 2009). The dollar fell, arguably not enough, but it did not collapse, partly as a result of a widespread 
'flight to safety' as international investors increased their dollar liquidity as the truly global nature of the financial crisis became apparent. Rather, the principal propagation mechanism was through an international version of the financial multiplier process (Krugman, 2008). A fall in asset values in one country depressed the balance sheets of highly leveraged institutions there, depressing the demand for financial assets in other countries, reducing asset prices in those countries and depressing balance sheets there, leading to falls in demand for assets in yet further countries, and so to a reduction in spending in those countries.

\section{SHORT-TERM GLOBAL POLICY RESPONSES}

What we have seen globally in the short run, since the crisis struck, has been an unprecedented policy response, designed first to limit the extent of the crisis and subsequently to halt, and then reverse, the downturn in demand. In the very short run the immediate response to the crisis involved a sharp reduction in (policy) interest rates combined with efforts to limit the paralysing effect of the credit crunch on the functioning of interbank money markets. The priority at this stage was to focus on the liabilities side of the balance sheets of the financial system and to provide liquidity to markets which were threatened by seizure, as a result of a massive increase in perceived counterparty risk. Over a slightly longer horizon, attention switched to issues of solvency. Fiscal authorities embarked on a range of schemes to recapitalize the banking system and to put in place fiscal stimulus programs, while central banks introduced quantitative easing (QE) measures aimed at cheapening longer term borrowing -i.e. at flattening the yield curve - and boosting private sector balance sheets by this means. We summarize these briefly below: more details can be found in the papers by Buiter, Frexias, Faruquee et al and Dale et al.

\subsection{Policy Responses at the national level}

\section{Lower interest rates}

The first action of most central banks was to cut policy interest rates sharply, in most cases almost to zero. Rates were first cut in the US as early as August 2007 and by September 2008 the US policy rate, was around $1.75 \%$ at which time Bank of England and ECB rates were still in excess of $4.50 \%$. From September 2008, rates in all countries were cut by unprecedented amounts. By the end of 2008, the US federal funds target rate was in a zone 
from $0 \%$ to $0.25 \%$ and the Bank of Japan's overnight rate was $0.10 \%$. The Bank of England and ECB followed suit, but remained at 50 and 100 basis points respectively. Not only did rates fall sharply from mid 2008 onwards, but they have remained on or close to their floor since then. ${ }^{32}$ Though large, such interest rate cuts were an entirely conventional response to a large negative demand shock, when viewed from the perspective of New Keynesian macroeconomics. ${ }^{33}$ Willem Buiter (this issue) makes a case for negative nominal interest rates to allow central banks to go beyond the zero lower bound. None has chosen to test this bound but rather have augmented interest policy with a range of additional monetary and fiscal measures including, in the immediate short run, large direct liquidity injections.

\section{Short-run liquidity to ease the credit crunch}

In the simple model which we presented in section 3.2 there is no liquidity problem. But, as Milne points out, after the collapse of Northern Rock, and of Lehman Brothers, concerns about institutions' liquidity and the possible seizure of short-term money markets became very serious. Once central banks had lowered interest rates to what they saw as their effective lower bounds, they resorted to very substantial liquidity injections, through the use of a number of channels. In part this occurred through international cooperation between the world's major central banks (for example through the expansion of the Fed's currency swap arrangements) and in part through increased lending by central banks against risky collateral As Frexias notes, the scale of these liquidity injections were unprecedented: in a matter of weeks after the collapse of Lehman Brothers, the balance sheets of the Federal Reserve and the Bank of England had doubled while those of the ECB and other major central banks had increased by between $30 \%$ and $50 \%$ over the same period.. This rapid and large scale increase in the monetary base - which stands in stark contrast to the contraction of the money base that occurred during the Great Depression -- clearly played a crucial role in avoiding the wholesale seizure of the global financial system. The papers by Frexias, Buiter and Dale et al (this issue) all describe in some detail how central banks around the world have developed non-traditional mechanisms for creating liquidity.

\footnotetext{
32 At the time of writing, countries are beginning to signal that policy rates will start to increase: by the beginning of 2010, Australia was the only OECD country to have started to raise the policy interest rate.

${ }^{33}$ A contrary view is advanced by Frexias (this issue) who argues that the large interest movements witnessed in response to the crisis would not have emerged from 'conventional' monetary policy actions but were prompted only by concerns about the fragility of the financial sector
} 
The lowering of central bank policy rates and large scale short-term lending to financial institutions was geared primarily to providing assistance at the short-end of the market. At the longer end, the focus was on rebuilding the balance sheets of banks and other financial intermediaries and on helping to bring long-term rates down in line with short-term rates. This latter process - named quantitative easing in the UK and perhaps more accurately credit easing in the US -- has essentially involved central banks in open market operations designed to increase the demand for long-term government paper, and private sector bonds, by central banks.

Financial markets, and indeed academic analysts, have found it difficult to understand what quantitative easing is doing. The problem for academic analysts has been that in models like that used by McKibbin and Stoeckel, which we described above, there are no highly leveraged financial institutions. As a result it is quite difficult to understand what quantitative easing is meant to do. In such a setup a central bank committed to recovery from the crisis would cut interest rates in the short term, and would then keep them low for long enough to ensure that the recovery actually happens. In a world where expectations were formed rationally, the yield curve would be such that long-term interest rates would fall low enough, and for long enough, to ensure that the recovery came about. What can QE hope to achieve in these circumstances?

There has been much nonsense written in response to this question. Whilst it is certainly true that the scale of QE activities tends to be measured in quantitative terms - in the UK, for example, by how much it contributes to the M4 money aggregate - it does not make much sense to analyse its impact in narrow old-fashioned monetarist ways. Despite the tendency of some commentators to do so, this is a distraction. ${ }^{34}$ The framework discussed above enables us to cut through this and to describe more precisely the role of QE. That model shows why, in the early stages of crisis, it seemed impossible to get long-term interest rates to fall in order to help with the recovery process. Our model suggests that, order to get HLFIs to take on an increase in their leverage ratio, which (as we have seen) a recovery would require, the yield

\footnotetext{
${ }^{34}$ See, for example, Congdon (2009) for an example of this perspective on QE.
} 
on long-term risky assets must rise relative to the short-term interest rate. This, of course, makes recovery more difficult. Another way of putting this point is that in the circumstances of the crisis financial institutions have wanted to increase margins in order to help rebuild their balance sheets, something which, of course, also tends to stop long-term interest rates from falling. Quantitative easing has been designed to deal with this problem. Our model suggests that if the central bank joins HLFIs (and other financial institutions not included in our model) in being prepared to acquire risky long term financial assets in exchange for the provision of short term, liquid, financial assets, then this will lower the price of longer term risky assets and so lower the yield gap between returns on longer term assets and interest rate on short term assets, even as the latter are falling. QE thus works through its effect on relative yields, rather than through any effects which it might have on the quantity of money. This is exactly why Bernanke (2009) drew the distinction between quantitative easing and credit easing when he stated "...to stimulate aggregate demand in the current environment, the Federal Reserve must focus its policies on reducing those spreads and improving the functioning of private credit markets more generally". This ability to have an effect on relative yields is something which, of course, is not present in the simpler models in which there is an expectations theory of the yield curve. It is this ability which explains the importance of undertaking QE, and which also explains why, so far, appeared to have been successful.

\section{Recapitalising the financial system.}

The second medium-term component has been the recapitalization of financial systems. Our model of asset price overshooting shows why recapitalisation of the financial system was necessary, and it also shows why such re-capitalisation has been helpful by, effectively, pushing out the supply curve for leverage and thus enabling HLFIs to bear further risk, and so prevent the prices of financial assets from falling further. More generally, in the real world we can see that doing this has enabled the financial systems to limit the reduction of lending by financial institutions which have balance sheets damaged by the crisis. This process of recapitalisation has been led by bailouts of the financial system in the US, and in Europe.

The specific form of bailout mechanisms have varied across countries: in some cases, for example the US and Switzerland governments have created bespoke publically-owned investment vehicles to hold 'toxic' assets. Elsewhere, including in the UK, governments have 
made direct capital injections. (See Stolz and Wedow, 2009, for a summary). In some cases, recapitalization measures have generated a rapid and substantial return to the public authorities (in the US, for example, many institutions have already re-paid TARP-related loans, while elsewhere the prices of toxic assets acquired by governments have risen off their floors. In other instances, however, recapitalization has entailed a significant increase in public debt. We discuss the medium-term implications of this below.

The deterioration of bank balance sheets during the crisis has been so severe that, despite significant re-capitalization, it has been in the interests of banks to continue to deleverage and so to curtail lending. This is making recovery harder for the rest of the economy. Furthermore, as recovery begins, it has become clear that it is also in the interests of banks - given their need to rebuild balance sheets - to increase the gap between lending rates and the rate at which they borrow, in the way described in Section 3.3.2. This difficulty is likely to further dampen the recovery, possibly very significantly.

\section{Currency depreciation (for some countries)}

As noted above, currency depreciation is the classic means by which a country recovers from a financial crisis - cheapening its goods in world markets and expanding through the consequential increase in world demand for its exports. Australia demonstrated the efficacy of this policy by managing to grow so rapidly through the Asian crisis, as a result of a very significant - approximately $30 \%$ - depreciation of the exchange rate in 1998. As described above, Asian countries did the same after the crisis and this, effectively, was the way in which they recovered so rapidly. Of course the crisis is a world crisis, and not everybody can devalue against each other. But particular countries, suffering from crisis in a disproportionately strong way can, and should, seek to devalue relative to the rest of the world. This clearly lowers the standards of living of those in that country - pricing goods into world markets means that the real consumption wages must fall. But doing this helps to ensure that the outcome is not one in which resources are unemployed. For the United Kingdom, currency depreciation is serving the economy well and is likely to have a significant impact on the form and pace of recovery. The same degree of exchange rate flexibility is not an option for the US, for the reasons outlined above or, indeed, for the individual economies of the European Monetary Union. 
Of course, in the modern world of floating exchange rates, the currency cannot be devalued as a matter of policy. But in a credible monetary policy regime, foreign exchange markets will know that policy will remain in an expansionary mode until demand has begun to recover. In such a world, markets will know that a country with a disproportionately large private sector downturn, such as Britain, will have expansionary monetary policy for a disproportionately long period of time. This will, of itself, puts pressure on the exchange rate to move in the required direction.

\section{Fiscal expansion.}

The final significant macroeconomic policy response has been a series of very large fiscal expansions, designed to continue to loosen the macroeconomic policy stance as policy interest rates converged on their zero lower bound (see Wren-Lewis, this issue). This has happened in the US, Japan, UK, Germany, Australia, and elsewhere in the OECD, and also particularly in China, and has received the strong support of the IMF (see, for example, Freedman et al, 2009).

A fiscal injection operates in the following way. The sustained downturn in private sector investment, and increase in private sector savings that combined to contract aggregate demand as the financial crisis spilled over to the real economy was, of course, partly counteracted by a reduction in interest rates, and, for some countries, by the effects of currency depreciation. But not entirely. In the short run a case could be made to run large fiscal deficits, to replace the missing private-sector consumption and investment. Buiter (this issue), considers in detail the circumstances in which fiscal expansion can be effective and beneficial. How effective such an expansion is likely to be is a matter of considerable debate, however. Corden (this issue), examines the effect of a fiscal stimulus using a simple Keynesian model in which interest rates are at their zero lower bound and there are, by definition, unemployed resources. In this setting the fiscal expenditure multiplier is at least unity and under reasonable assumptions about the propensity to consume, substantially higher.

These large values stand in contrast to the significantly lower values used in much of the policy discourse over the last year. In its briefing for the London G20 Summit in April 2009, the IMF suggested that fiscal expenditure multipliers might lie between 0.5 an 1.8 for public investment and 0.3 and 1.0 for other government expenditure (see Spilimbergo et al, 2009). 
Whey are these multipliers so low, and so much less than unity? One possible reason is empirical. The multipliers quoted by the IMF are, to a large extent, point estimates of the average size of fiscal multipliers derived from data drawn from 'normal times' where, the (negative) output gap was not as large, where inflation was not 'stuck' but driven by a relatively steep Phillips curve, and where interest rates responded according to a Taylor rule rather than being at or near their lower bound. In this empirical setting, crowding out effects (including interest rate reactions) will be important and will tend to bias the multiplier downwards.

But a second reason arguably reflects the direction in which modern macroeconomics has moved. Benchmark models tend to assume representative agents' that typically smooth their consumption intertemporally; are able to optimally determine their labour supply (to equalize the marginal utility of consumption with the marginal disutility of work); and to respond to fiscal policy in a Ricardian fashion. Such models also assume that monetary policy follows a conventional Taylor rule. As Hall (2009) emphasises, models in this tradition will tend to generate low values for the multiplier.

But the reality during the crisis is very different: interest rates were on their lower bound; there existed substantial unemployed resources, including labour; and because of the crisis in the financial sector, many consumers were credit-rationed and thus unable to smooth consumption over time. In such circumstances, it is reasonable to assume that the fiscal expenditure multiplier is larger than the IMF estimates might suggest, at least in the shortrun. $^{35}$

Another way of viewing a fiscal stimulus is in stock rather than flow terms. We can view the crisis as creating the need for a large increase in the supply of claims on the public-sector assets to replace the reduction in private sector wealth brought about by the collapse in house prices, and, subsequently the collapse in equity values. Since the lowering of interest rates, failed, on its own, to stimulate a sufficient fall in the private sector demand for assets, the public sector needed to go into deficit; and since the private sector disequilibrium was so large it needed to do this by unprecedentedly large amounts. This increase in public debt - the

${ }^{35}$ Christiano et al (2009) show how even the simple expedient of augmenting a Taylor Rule with a zero-lower bound constraint in this class of model will substantially increase the size of the fiscal multiplier. 
counterpart to the deficit - has been required precisely because the private sector has wished to save and, in the short run, has been unwilling to invest. In addition the collapse in the balance sheet value of the financial sector - leading to deleveraging in the way which we have described above - has required that public debt be issued to finance the recapitalisation of these financial institutions, and, in the case of the Royal Bank of Scotland, and of LloydsBank of Scotland in the UK, to finance the taking of these banks into public ownership.

A key question from this point of view an inter-temporal one. Is the resulting increase in public debt a burden on future generations? Max Corden (this issue), makes the case that it is not. Using a simple two-period model, he argues that, as a result of the fiscal stimulus, output and hence incomes in the first period rise, increasing both consumption and saving, with the latter benefitting persons living in the second period. Those living in the second period are also, of course, left with an increase in their tax liabilities. Crucially, however, the increased tax liabilities in the second period are exactly matched by the increased savings passed from the first to the second period. Hence, on balance, (i) those in the first period benefit from the increased income, employment, and consumption in that period, and (ii) those in the first period are not passing on any burden to those living in the second period.

How does this finding connect with the common view that such a fiscal injection will cause an increase in the debt burden? The answer lies with the counterfactual being considered. Compared to the situation in which there had been no crisis in the first period, the economy will, of course, have a higher level of public debt. This is a necessary outcome of the increase in public expenditure which was used to 'fix' the crisis in the first period. It is also the case that macroeconomic equilibrium post-crisis requires higher taxes in the second period than if the economy had been undergoing normal growth in both periods. However, as Corden argues: "...opposing the use of fiscal policy to deal with ... a crisis on the basis that it creates a burden on future generations in effect amounts to a belief that the crisis would fix itself some other way." Future generations are more burdened by fixing the crisis by means of fiscal intervention than they would have been had the crisis fixed itself some other way. Butas stated above - they are not more burdened compared with an outcome in which there had been no fiscal intervention, and, as a result of that, output had been lower.

Corden's paper, which sets out to develop the simplest possible model within which to discuss the role of a fiscal stimulus, sets the scene for the discussion of a broader set of 
questions concerning both the question or the interaction between fiscal and monetary policy, which are discussed in the paper by Wren-Lewis and issues of fiscal policy and intergenerational balance, as discussed by Barrell and Weale (this issue). We return to these issues ourselves in Section 5.3 below.

\subsection{International Macroeconomic Policy Cooperation - a short-term perspective}

As the crisis unfolded from late 2008 onwards, calls increased for international cooperation and a coordinated policy response. These led to the G20 London summit, at the beginning of April 2009, which was widely hailed as a landmark in international policy cooperation. What exactly happened at that meeting?

From a formal perspective, it is possible to show that in the face of a general economic downturn, when the only policy instrument is monetary policy, no issue of coordination arises, providing that all policymakers are 'playing the game' (See Luk and Vines, 2010b.) Each policymaker would like to use monetary policy to counteract the downturn, but might hesitate to do so, since this might cause the currency to depreciate and expose the country to inflationary pressures. But if all countries were to embark on a monetary expansion together, then they would not put pressure on any one currency to depreciate relative to others, and so the risk of inflation would go away (McKibbin, 1988). Hence, for monetary policy actions (including the provision of short-run liquidity and quantitative easing measures) the most important aspect of cooperation was that of information exchange: we required a global policy-making environment in which each nation knew that other nations were acting. The G20 and particularly the IMF played a crucial role in providing this information exchange.

These simple requirements are not sufficient for fiscal interventions, where by this term we include the recapitalisation of the banking system. The reason, put simply, is that while fiscal injections stimulate aggregate demand, some of which leaks into the demand for imports, these policies also generate an obligation to raise taxes in the future, compared with an outcome in which the crisis was fixed in some other way. Given that fiscal expansion by any one government creates positive spillovers to other countries, each government would prefer a recovery to come from a disproportionate extent from fiscal injections elsewhere in the world, so that other countries bore the (future) fiscal costs. Ensuring a globally desirable degree of fiscal stimulus in the face of this free-rider incentive requires international policy 
coordination. This explains why we saw such a large emphasis on the need for co-operation about fiscal injections in the run up to the G20 summit in London.

The need for cooperation will be different in the medium term to longer term. It is to that time period that we now turn.

\section{LONGER-TERM MACROECONOMIC ISSUES: ENSURING SUSTAINABLE GLOBAL GROWTH}

As we write this paper, it appears that the short term policies of stimulus have succeeded in preventing what was a very severe crisis from leading to another Great Depression. Policymakers seem to have learned enough from the Keynesian revolution, and from a historical understanding of the Great Depression, to avoid the mistakes which were made then. They have certainly used cuts in interest rates - the New Keynesian weapon of choice to deal with a slump in activity. But they have also used a range of other instruments recapitalisation of the financial system, quantitative easing which and fiscal injections. Each of these, in some way or other, has involved dealing with the balance-sheet issues that are not studied in New Keynesian analysis.

But what about the longer term? In this final substantive section of the paper we consider some of the major challenges that will confront policymakers in the immediate aftermath of the crisis and beyond, at both the national and international levels. Two major issues stand out. At the national level, we will need to deal with the fiscal imbalances which contributed to the crisis, and which then worsened, because of the policy actions taken, in the short-run, to deal with it. At the international level, attention must now centre on rectifying the imbalances between savings and investment in many significant countries. These are both also, in the end, balance sheet issues. No fiscal authority can go on living beyond its means, indefinitely. And neither can any nation state.

\subsection{Monetary policy: sustaining inflation targeting regimes}

The inflation targeting frameworks that have anchored monetary policy in most major economies over much of the last 15 years, have been heavily criticized in many quarters for being, in part, responsible for the crisis. Critics argued that the narrow mandate and relatively 
short horizon over which targets were defined led policymakers to pay insufficient attention to asset price inflation, to excessively lax credit conditions and the build up of financial imbalances that preceded the crisis. From this followed calls for reform, ranging from the operational, for example, that central banks should seek to 'lean against the wind' of asset price movements, to the radical redesign of the framework of monetary policy, including even calls to abandon inflation targeting regimes in favour of more discretionary regimes (see Wadhwani, 2008 and White, 2009, for a flavour of this critique).

Though headline-grabbing, this critique has not attracted widespread support in academia or from central banks. Here, the view prevails that the essential framework of inflation targeting regimes remains robust. This view sees inflation targeting regimes in the context of the fundamental 'assignment problem' in economic policymaking: how responsibility for meeting different policy objectives - price stability, financial sector regulation and fiscal policy should be assigned across different instruments and/or institutions (Allsopp, 2009). Inflation targeting represented a pragmatic solution to the problem of assigning responsibility for inflation control and - subject to that - for the stabilization of output around the natural rate. The institution was typically central banks and the instrument typically interest rates. The key point here is that inflation control and output stabilization was only part of the assignment problem and while operational errors were probably made in the conduct of monetary policy, the crisis owed much more to failures elsewhere, specifically in the areas of financial sector regulation and fiscal policy. As the Governor of the Bank of England, Mervyn King, noted in his 2009 Mansion House speech: "Inflation targeting is a necessary but not sufficient condition for stability in the economy as a whole. When a policy is necessary but not sufficient, the answer is not to abandon, but to augment it." (King, 2009a). Any attempt to make monetary policy do 'too much' risks not only failing to meet these additional objectives but failing to deliver on its core mandate.

The paper by Dale et al (this issue), presents this line of argument and discusses in more detail the specific points of the critique. Similar points are made by Buiter and by Milne. Batini and Tereanu (this issue) provide a quantitative assessment of the costs - measured in terms of output and inflation volatility and the implied volatility of interest rates - of a loss of credibility in the monetary policy regime. 
One important medium term question for central bank operations is their exit strategy from QE. Again much of the concern expressed about the exit strategy appears to emanate from the monetarist interpretation of QE programs. But the logic appears simple: as recovery comes, and the economy returns to a more normal situation, the leverage constraint on banks will ease and the yield curve will come to resemble more closely the private sector's beliefs about the central bank's expectations of what interest rates will need to be in the future in order for the central bank to satisfactorily follow its inflation targeting regime, in the light of what it expects about the shocks which will hit the system. Hence, since QE was introduced in order to steer the yield curve in the desired direction, it follows that QE can be unwound as, and when, the private sector itself gradually pushes the yield curve back to its appropriate place. The task of the central bank is therefore to structure asset sales so as to preserve a yield curve which is consistent with the bank's inflation target and output objectives and to ensure that such sales are not themselves a source of asset price volatility.

As interest rates begin to rise in the course of recovery bond prices will fall, confronting central banks with balance sheet losses on the assets which they have acquired during the QE process. Increases in interest rates during a recovery always increase the fiscal costs of debt service faced by government, but these tend not be of direct concern to independent central banks. However now, as QE is unwound, and central banks have to actually sell the assets which they have acquired, accounting losses will be turned into actual losses. A concern has been expressed that this potential effect of higher interest rates on central banks will undermine their credibility. In particular it might make them reluctant to raise interest rates to control inflation as the recovery gets under way. Furthermore, if they need to seek financial support from the fiscal authorities to re-build their own balance sheets, this might compromise their independence, further undermining their ability to pursue their other policy objectives (See Berrial and Bhatterai, 2009).

All of this discussion presupposes - from a world-wide point of view - that monetary policy can be safely delegated to individual nation states. We noted above that, faced with a general slowdown in demand, there is no strong case for international coordination of monetary policy, beyond that of information-sharing. However Posen and Subramanian (this issue) return to the question of whether international coordination of monetary policy might be desirable in the face of global inflationary difficulties - of the kind which existed in early 2008, immediately before the crisis, and which might again re-emerge as global recovery 
gathers pace. The famous view from the 1980s was that delegating inflation control to individual economies in the presence of shared inflation might lead to excessively contractionary outcomes - as countries sought to export inflation to each other, by seeking to appreciate their exchange rates vis a vis each other. (McKibbin, 1988) However, that view fell from favour, essentially because its claims turned out to be empirically unimportant. But Posen and Subramanian turn the conventional wisdom upside down. They argue that, in a world in which the global inflation of primary commodity prices is a significant problem, the use of national monetary policies to control inflation might give rise to outcomes which do not fight global inflation resolutely enough. This is because fighting inflation in any one country reduces world-wide inflationary pressure coming from global primary commodity markets - a positive externality. But, they argue, national policy-makers will not internalize this externality, and so nobody will "own" the global inflation problem. ${ }^{36}$ In our current world, in which projections suggest that primary commodity prices might move up again as the recovery gets underway, their claim may turn out to be extremely important empirically. As a result, this may well have significant implications for the coordination of national economic policies which we discuss in Section 5.5 below.

\subsection{Fixing the financial regulatory system}

Arguably the greatest policy failure causing the crisis was the inability of systems of financial sector regulation to contain the growth of excessive, uncovered, risk-taking amongst financial institutions. We noted above how the 'search for yield' propelled financial institutions to take on more risk - and we modelled this, in our simple macroeconomic model, as an increase in leverage. This incentive to take on more risk was encouraged, at least implicitly, by environments in which limited liability provisions, deposit insurance and state-support for institutions deemed 'too big to fail' left taxpayers facing the cost of unprecedented rescue operations. Alessandri and Haldane (2009), for example, suggest that public-sector support to financial institutions in the US, UK and Euro Area during the recent crisis has totalled US\$14 trillion, equivalent to almost $25 \%$ of global GDP.

Post crisis, regulatory reform appears to be moving in two directions (see Milne and Frexias in this Issue and also Alessandri and Haldane, 2009). The first has concentrated on

\footnotetext{
${ }^{36}$ Luk and vines (2010b) prove formally that, in these circumstances, welfare can be raised by a more contractionary policy than that which would be pursued by individual countries, acting independently.
} 
addressing evident weaknesses in the Basel Committee regime that has shaped financial sector regulation over recent decades. Thus attention is being focussed on questions of capital (and liquidity) adequacy and the limitation of excessive leverage (including macro-prudential' requirements to create counter-cyclical buffers in banks' capital structures); on disclosure rules, information and risk management mechanisms; and on the extension of the regulatory net to non-bank institutions including hedge funds and other investment companies. ${ }^{37}$

The second element, is concerned with addressing the moral hazard problems associated with institutions that are 'too big to fail' or 'too connected to fail.' The Financial Stability Board, set up at the G20 meeting in London in April 2009 has been examining various policy responses to this type of market failure including competition policy aimed at limiting the size of banks, and the development of 'living wills' - ex ante plans for recovery, break-up or closure of a firm experiencing difficulties. In early 2010, the Obama Administration proposed legislation to enforce greater separation of deposit-taking banks' proprietary trading from their commercial banking activities - the so-called 'Volcker Rule' - in effect, restoring Depression-era Glass-Stegall Act in the US, which was repealed in 1999 (Financial Times, 2010). Similar proposal have been made by the Governor of the Bank of England (King, $2009 \mathrm{~b}$ ). To date, few concrete proposals addressing these problems have emerged and there is a risk that moves in this direction will be blocked by vested interests.

\subsection{Resolving Fiscal Imbalances in the Longer Term}

The need to control the public sector deficit- the flow supply of public debt

When the recovery comes, fiscal positions will come under strain. This is because private sector consumption and investment will recover, offsetting the increase in private sector savings, and reversing the reduction in private sector investment which has happened up until now. The value of the wealth of the private sector will have recovered. (This is simply the counterpart of the increase in public debt, and analysed by Max Corden which we discussed above). At this point, the large fiscal deficit risks becoming excessive - with public spending too high and taxes too low - a risk which, at its simplest, is present because of the increased

\footnotetext{
37 Alessandri and Haldane (2009) make the point that because of the market structure - a large number of small funds operating with low entry and exit costs -- hedge funds were not a source of systemic risk in the recent crisis, despite being demonized in the popular press.
} 
servicing burden of the extra public debt. At this point there will need to be an increase in taxation (or a cut in public expenditure) in order to prevent the further increase in public debt, and the resulting debt-interest receipts accruing to holders of the debt, from causing such a large increase in consumption that it causes excess demand. ${ }^{38}$ Of course, if this fiscal discipline does not eventuate then a greater burden of macroeconomic management will be thrown back onto monetary policy, requiring interest rate increases of a kind which would threaten the sustainability of the recovery.

What will be needed to make such fiscal discipline possible is both a return of growth - and so growing tax yields - and a willingness to raise taxes, and/or cut public expenditure. This will be the means by which the supply of public-sector debt ceases to increase as a share of output. There is a difficult issue of timing to be achieved here. In the short run, as described in Section 4.1 above, the public sector must supply enough assets, to be held by the household sector as it increases its saving, and to be held by the financial sector as it deleverages out of its holdings of risky assets. But in the long run as growth returns this flow position must be reversed - i.e. the budget deficit must be curtailed. Discussions of the budgetary position in the US, the UK and elsewhere make it clear just how politically difficult it will be to raise taxes in the required way.

\section{The need to control the stock of public debt}

Whether the stock of public-sector debt should be reduced (relative to GDP) following the crisis and, if so, by how much and how rapidly, is a much harder question to answer, however. As Wren-Lewis (this issue) shows, in a benchmark model of an endowment economy populated by infinitely-lived agents (so that issues of inter-generational transfers do not figure) the optimal fiscal strategy would be to 'accommodate' any increase in debt caused by a fiscal stimulus, and accept a permanently higher marginal tax burden in order to service this debt. ${ }^{39}$, More realistic models in which debt is, at least partially, set in nominal terms, or if it is real but prices are sticky tend to deliver the result that the optimal fiscal strategy will

\footnotetext{
${ }^{38}$ At the time of writing this process of reversal of the fiscal stimulus is already underway. Australia and Israel lead the world in having already begun this stimulus-reversing process.

39 This result is a direct implication of Robert Barro's well-known 'tax smoothing' model where, in the face of rising deadweight losses from taxation, it is optimal to smooth tax rates so as to avoid excessive tax distortions. Attempts to reduce the debt ratio following an adverse shock would represent a direct violation of the tax-smoothing argument.
} 
entail reducing the public debt ratio back towards its pre-shock equilibrium - so called, 'debt targeting'. One reason is time consistency: the authorities will have an incentive to reduce the debt burden through (non-distortionary) surprise inflation, which renders a policy of debt accommodation time-inconsistent.

\section{The underlying national savings issue}

An alternative reason for debt targeting is that it will help an economy deal with an overall shortage of national savings and the crowding out of private investment which this might cause. Ray Barrell and Martin Weale (this issue) tackle this concern. They argue that insufficient national savings was an additional feature of the macroeconomic environment in the run-up to the crisis. They would not deny that low interest rates, and low national savings, were necessary to keep the great moderation going, in the way which we have analysed in Section 3.1 But they take a long hard look at the balance sheet implications of this low level of savings for those who lived within the countries where it was brought about.

Barrell and Weale do this by going beyond the kind of framework on which we have been relying up until now, and make use of an overlapping-generations perspective. In such a framework an economy's savings - and thus its ability to accumulate productive capital depend on the balance sheets of each generation, and, in particular, on whether the young generation accumulate enough savings to afford them a satisfactory standard of life when they are old and retired. This is clearly the appropriate setup one for thinking about issues of public debt and fiscal policy, since it provides a framework in which one may examine whether public debtreduces the amount of savings left for investment, and so effectively crowds out the stock of equity issued by private firms. The fundamental point made by Barrell and Weale is that Anglo Saxon economies have not saved enough - and may go on not saving enough and that the reasons for this are partly fiscal. They are concerned to show that this excessively low level of savings may have potentially serious longer term consequences.

One reason for excessively low savings is the political economy of pension provision. As a result of pay-as-you-go pensions systems in many countries, young people do not save enough for when they are old., meaning that the stock of capital ends up too low A second reason for too low a level of savings was the result of a long period of rising house prices. Such increases create 'imaginary' increases in housing wealth which the younger generation 
come to believe that they will be able to utilise to sustain them when they are old. As a result they are persuaded to save too little. Finally, Barrell and Weale suggest that savings was too low for a third reason. They suggest that, in the last 15 years (perhaps partly as a result of the dot-com boom) those in work made a mistake, in thinking that the future value of their savings, including their pensions, would be higher then it has actually turned out to be. It is possible that they consumed too much and saved too little, for this reason too.

The implication of the Barrell and Weale paper is that fiscal regimes in many advanced economies - particularly Anglo Saxon economies - require radical reconstruction to ensure that current saving levels are enhanced, for two reasons. Firstly, the generation which are now old will - they imply -demand to be bailed out in some way by the state-funded pension system, and by other means, worsening the fiscal position. ${ }^{40}$ And the younger generation will need to be forced to pay higher taxes, or public expenditure must be reduced, so that a more adequate level of public pensions provision can be built up, to prevent the same thing happening again.

The message of the Barrell and Weale paper, viewed from a political economy perspective, is that there is a significant political struggle ahead, in the US, the UK and other advanced countries, about these fiscal issues. ${ }^{41}$ One the one hand it may be that the older generation might be denied what they want, the younger generation might be forced to pay more taxes, and public services might be reduced. On the other hand this might not be possible. The medium-term macroeconomic risk from the Barrell and Weale paper is that a sustained recovery might be jeopardised by a fiscal crisis, or, more gradually, by sustained underlying fiscal difficulties. The issue of timing remains important. None of this suggests that fiscal timing should be begun before the private sector recovery is underway. But in due course, as the recovery comes, the government sector will need to step back and make room for the issue of private debt.

\footnotetext{
${ }^{40}$ This statement incorporates the idea that health provision will be expanded, partly at state expense to support a generation of people living longer than had been expected.

${ }^{41}$ Barrell and Weale are particularly concerned about distributional effects of past and current saving on the standard of living of those who are young now, and will have to pay extra taxes, and suffer from reduced public services, to support the bailouts of those who are old now and expect to be bailed out in the next few years. Their analysis paints a grim picture of the future that these younger people will face.
} 


\section{The Risk of Higher Interest Rates}

However, many in the financial markets appear to question whether political institutions are strong enough to ensure that the necessary fiscal adjustment occurs when the time comes. This concern can cause -- and as we write does appear to be in danger of causing -- long term interest rates to be higher than they otherwise should be, in the US, the UK, and elsewhere. Unless something is done, this may actually impede the recovery. (See Besley, et. al 2010, Layard, et.al. 2010).

We do not believe that the rise in long-term interest rates reflect an outright-default risk premium on public debt. Nonetheless, the absence of a clear fiscal strategy may cause interest rates to rise for two main reasons. First, as noted above, it may be feared that the burden of macroeconomic management is thrown back on monetary policy, requiring that, in the future, there would need to be increases in the real interest rate. The expectation of this, now, could cause long term interest rates to rise, now, in a way which would threaten the sustainability of the recovery.

Second, it may be feared that central banks will be prevailed upon to renege on their commitment to fighting inflation in the future, as the recovery gets under way. It might be argued that 'it is desirable to inflate the public debt away, so as to remove the prospective burden of higher taxes'. ${ }^{42}$ But if there is a fear that the inflation targeting framework is not strong enough to prevent this happening, long term interest rates will rise in the short-run, not because of a fear of higher real interest rates in the future, but because of a fear of higher nominal interest rates in the future, as inflation sets in. Such a fear of future inflation will also hinder the recovery in the short-term. ${ }^{43}$

\footnotetext{
${ }^{42}$ Woodford has, until recently, offered an alternative positive case for promising higher inflation above the normal target levels -for some time in the future. Knowing that inflation in the future will be higher, forward-looking agents will not allow disinflation to happen in the present. As Wren-Lewis (this issue) notes, however, this is a time-inconsistent strategy, since when the future time comes, the authorities will not wish to create inflation, and so jeopardise the credibility of their anti-inflation strategy. Such a strategy has not been promised by central banks.

${ }^{43}$ Concerns about fiscal credibility offer a further reason why QE has been helpful. In a world in which there is insufficient confidence in the ability of governments to control the fiscal deficits created in response to the crisis, expectations of future short-term interest rates may be unhelpfully high, preventing long term interest rates from falling. This problem is particularly severe if policymakers are, in fact, of the kind that will discipline fiscal policy in the future, but market participants are not confident that that they will be able to this - even though they will. In these circumstances, QE is a useful signalling device, in letting the markets know the central bank's expectations about the likely
} 
This discussion highlights a significant credibility problem in the fiscal strategy which we have been describing. We have suggested that fiscal policy should be loose in the near term, but tightened in the future as the recovery comes. But we have also highlighted political reasons as to why the required tightening in the future might be resisted - or why policymakers might come under pressure to, at least, delay the necessary interest rate increases, as recovery comes. It is critical that fiscal institutions are sufficiently robust to confront this problem. Whether they are clearly varies across countries. In the UK, for example, it seems almost certain that the inflation targeting strategy will survive intact and that robust policy-making institutions will deliver the necessary fiscal adjustment, albeit one that hands a rather bleak fiscal future to UK inhabitants, particularly for the currently young. Elsewhere, including in the US, it is less clear that fiscal policy-making institutions, as currently configured, can do likewise. This why many people, including Wren Lewis (this issue), are advocating fiscal responsibility councils, whose position is made independent from day-to-day politics. The analogy is drawn with central banks, which have been made independent, to guard against related credibility problems. These central banks now operate with a degree of independence which would have seemed surprising 25 years ago. It may be that a similar institutional change is required for fiscal policy. ${ }^{44}$

Of course, in an integrated world economy, there is an alternative to rising real interest rates. This is that, instead, the currency appreciates and the countries concerned run a currentaccount deficit. What we have described above about the fiscal risks, particularly in the US, suggests that there are risks of the re-emergence of what happened at the time of the Greenspan put. Overspending will continue, the currency will not depreciate enough, and this overspending and insufficiently depreciated currency will be reflected in a continuing currentaccount deficit. As viewed from the point of view of the deficit countries, there is a risk that the problem of global imbalances will not be resolved.

\subsection{Resolving Global Savings-Investment Imbalances in the Longer Term}

\footnotetext{
future success of the fiscal authorities in dealing with their fiscal crisis.

${ }^{44}$ Timing issues mean that the credibility problem will be more difficult to solve with fiscal policy. It is clear within a year or two if monetary authority has reneged on a commitment to target inflation. Experience in the UK has shown that it can take a decade or more to determine whether a fiscal authority has reneged on a commitment to fiscal prudence.
} 


\subsubsection{Three Kinds of Risks}

Despite the short-run stabilization success of macroeconomic policy, it has not been successful in dealing with the significant savings - investment imbalances which occurred during the decade before the crisis. As we discussed above, these imbalances played a part in causing the crisis, in that they led to abnormally low rate interest rates for a considerable period of time which, in turn, caused leverage to explode in the financial system in a way which led to overshoot and collapse. Portes (2009) and Obstfeld and Rogoff (2009), and Blanchard and Milesi Ferretti (2009) argue convincingly that any longer term resolution of the crisis, and any construction of a robust framework in which crises are less likely, will require that the asymmetric savings-investment gaps, and so the global imbalances, are resolved. That is, we require an outcome with two features. First, the fiscal pressures in the US, the UK and other large current-account deficit countries need to be resolved so that net exports may expand, with this expansion being facilitated by a devaluation of their real exchange rates. But also, second, we require an outcome in which there is a disproportionate expansion of domestic demand in the surplus countries, supported by an appreciation of their exchange rates. Bringing about this adjustment will not be straightforward.

\section{Risk of continuation of insufficient savings in Anglo Saxon countries}

One risk is that there is excessive reliance on recovery of domestic demand in deficit countries, in particular in the US. That too would be part of an outcome which set the whole process off all over again. The UK has already devalued significantly, and its recovery will be assisted by a depreciated real exchange rate. Because the UK is a small economy the effect of this sterling depreciation in causing an appreciation of the currencies of other economies will be small, and thus not particularly significant. ${ }^{45}$ But of course this cannot be achieved for all deficit countries. In particular it cannot be achieved by the US - without there being significant depreciation of the dollar against another major region of the world.

This links the problem of global imbalances with the problem of public debt discussed above. One important implication, which we will discuss, is that the level of public debt, and the flow budget deficits, must be consistent with the resolution of global imbalances. The fiscal

\footnotetext{
${ }^{45}$ This is not true of Ireland, however, which trades heavily with the UK and competes directly against the UK in third markets.
} 
discipline necessary in the deficit countries - in particular in the US - must be greater than the fiscal discipline required in the surplus countries. This could easily go wrong. As we have noted above, in the absence of fiscal discipline in the US, global markets might come to fear that US interest rates will rise - either to control inflation, or as a result of the US attempting to inflate its way out of the crisis. Fears of this could cause longer term interest rates in the US to rise. This could then cause the dollar, and currencies of other deficit countries, to rise, putting at risk the correction of global imbalances.

\section{Risk of inadequate increase in consumption in emerging market economies}

A converse risk is that there is insufficient recovery of domestic demand in the surplus countries, such as Germany, Japan, and countries in East Asia, including China, which up until now have been reliant upon growing exports. China appears to be moving in the required direction, but there are very real difficulties in producing a sufficient expansion in domestic demand, even though the fiscal injection has been very large. At present savings in China are high, not just for the reasons described earlier in this paper, but also because of the high level of profits, both in the old state enterprises, and in the rapidly growing private sector. Profits are not being distributed to the household sector, in a way which could stimulate an increase in consumption, but are instead being used to fund investment. And a large fraction of the fiscal stimulus has been used to finance large increases in public infrastructure investment, rather than to finance increases in consumption. Yu Yongding (2009) argues that this adjustment process in China is not sustainable. In due course, he argues, the extra investment will create extra capacity to produce output. If that capacity is to be fully utilised, then demand must grow. If exports remain curtailed, and private savings remain high, then the only way to increase demand might be to increase in investment, yet further. $\mathrm{Yu}$ is worried that this process may create an unstable upwards spiral, which would inevitably have to collapse downwards.

There is a long-run solution to Yu's problem, in the form of a more rapid increase in wages. That would tend to encourage all methods of production to become more capital intensive, helping the extra savings to be absorbed, without requiring an ever-growing increase in the 
proportion of national income devoted to investment. ${ }^{46}$ It would also tend to encourage consumption. But there is a real worry as to how quickly this adjustment in factor prices, and in production technology, will actually happen in China. The longer it takes, the longer Chinese policymakers will to continue to seek an outlet for their growing production through exports - pushing the world back towards the unsustainable outcome which led to the current crisis. It appears that for domestic political reasons China may not be in a position to ensure the rapid recovery in consumption, and the demand-driven appreciation of the renminbi this would entail.

In any case, the required appreciation of the Chinese exchange rate also will be difficult to bring about. Estimates widely suggest that the Chinese currency is 30 or 40 percent undervalued. ${ }^{47}$ This cannot be corrected, in a large immediate movement, without bankrupting firms geared towards producing for export. What is required is a gradual appreciation of the real exchange rate, at a rate of 4 or 5 percent per annum for say 10 years, over which time the current overvaluation of the exchange rate would be removed after allowing for continued increases in Chinese competitiveness, as compared with that in the US and other advanced countries. But such a gradual appreciation offers opportunities for speculative benefit, creating the possibility of large capital inflow in search of capital gains. These could bring the appreciation forward, creating the possibility of a 'reverse' currency crisis in which the renminbi appreciated greatly. Any attempt to moderate such capital inflow by setting lower interest rates within China would be vulnerable to the possibility that this would stimulate a too great growth in domestic demand, in the form of investment. Making a successful move in the required direction of currency appreciation seems to necessitate sufficient restrictions on capital movements so as to prevent the capital inflow from destabilising the process. ${ }^{48}$ Movements of the currencies of other Asian countries will become much easier if the Chinese currency appreciates.

\section{Risk of Squeeze on Europe and its consequences}

\footnotetext{
${ }^{46}$ This increase in wages, as capital grows faster than labour, is exactly what Solow (1956) supposed would happen in the Harrod-Domar growth model, if the 'warranted' growth rate was faster than the 'natural' growth rate.

${ }^{47}$ Obstfeld and Rogoff $(2002,2007)$ have been resolutely pushing the argument that the dollar must devalue, ever since 2002. See Obstfeld and Rogoff (2009) or a recent recapitulation, and extension, of this argument.

${ }^{48}$ It is possible that liberalising the financial system within China, in such a way as to encourage an increase in holdings of foreign financial assets by Chinese residents, might create a counterbalancing capital outflow which could offset any capital inflow.
} 
If the currencies of East Asia do not appreciate, but financial market pressure forces the dollar to devalue, then the world faces significant regional tensions. It is only possible for the dollar to devalue, and at the same time for currencies in East Asia not to appreciate, if there is significant appreciation of the euro. This will make recovery in Europe difficult.

As recent events in Greece highlight there are also significant internal imbalances within Europe which are likely to make these difficulties worse. Germany has been running a growth strategy based on an improvement of competitiveness with respect to the remainder of the EMU region, relying on the fact that Portugal, Greece, Spain, Italy and Ireland are significantly uncompetitive. These countries are unable to carry out as large fiscal expansion as might be appropriate, since, with disproportionately large falls in output, tax revenues have collapsed, and budget deficits are so large that further expansion is deemed irresponsible. As a result, expansion within the Euro zone depends upon expansion of domestic demand within Germany, or the attainment of a more globally competitive position of the euro region as a whole. But, if as described above, global pressures cause the European currency to appreciate, then the latter strategy becomes unavailable. In that case a recovery of growth in Europe depends fundamentally upon expansion of demand in Germany, either expansion of private demand, or if that is not possible, further fiscal expansion. Since Greece, Portugal, Spain, Italy and Ireland are all so uncompetitive, the required expansion in Germany is likely to be larger than the expansion which Germany itself would willingly undertaken. There is a risk that Europe faces an intermediate-run outcome in which (i) much of Europe is uncompetitive although Germany is not, and (ii) to avoid inflationary pressures in Germany European demand expands much too slowly to absorb unemployed resources in Greece, Portugal, Spain and Italy and Ireland. (See Allsopp and Vines 2007, 2010, and Wolf, 2010a, 2010b)

Indeed it is possible that the difficulties just described might create a new crisis, which aborts the recovery in Europe, and endangers the entire global recovery. Fears of fiscal default in Greece are creating a large risk premium on public debt in Greece, which of course is making the fiscal deficit position worse, and so validating these fears. What Greece needs is an improvement in competitiveness relative to Germany and most of the rest of Europe, and - at the same time - a fiscal contraction to stop Greek public debt from spiralling out of control. Such a contraction which would be made politically easier by an increase in Greek exports 
resulting from an improvement in the country's competitive position. But because of Greece's membership of EMU such an improvement in competitiveness may be difficult, or impossible, to bring about, meaning that the required fiscal correction may become politically impossible to deliver. ${ }^{49}$ Many countries belonging to EMU are suffering from similar problems to those suffered by Greece - the so-called PIGS (Portugal, Italy, Spain and Greece - and Ireland too). Some others - new members of the EU in the East of Europe - are not yet members of EMU, but operating pegged exchange rates, as part of the required process of convergence towards EMU membership. These pegged exchange rates seem highly vulnerable to speculative attack. The implications of a bad outcome in these countries are worrying. Fiscal default by any of these countries would be likely to spread, by contagion. Such an outcome would make the collapse of Lehman Brother look like a tea party.

\subsubsection{What if Medium-term Adjustment does not happen? Two possible Scenarios}

Of course, everything might turn out fine. The US and other low-saving countries might put their houses in order. The high saving countries might expand sufficiently. And we might get by without an internal crisis within Europe.

However the risks in the medium term do not seem small. There seems to be the possibility of two rather different outcomes, each bad, but in different ways. ${ }^{50}$

The first rather bad possibility is that fiscal discipline succeeds in bringing spending down in the low-saving countries, but that the high saving countries do not expand enough. The world will then require stimulative monetary policy and the US seems to be the only country capable of delivering this. If this happens, we will go back to an outcome in which the present recovery is sustained with very low world interest rates, an outcome in which global imbalances are not removed. As we have argued in the central part of this paper, periods of low interest rates put huge pressures on global financial markets, encouraging excessively high leverage. In these circumstances, we see the risks of going back to the beginning - circa 2002 -- and starting all over again.

\footnotetext{
${ }^{49}$ See Issing (2010) for a spectacularly clear statement that what Greece needs to do in present circumstances is knuckle down and submit to discipline. As we write it remains an open question as to whether this will be possible, politically. And what Issing misses is that some large part of Greece's problem is caused by Germany's fiscal strategy. Wolf (2010b) makes this point very clear.

${ }^{50}$ Blanchard and Milesi Ferretti (2009) present some additional, thought-provoking, scenarios.
} 
In this scenario, it is quite possible that the dollar falls, but that countries in Asia resist the appreciation of their currencies. Although interest rates would be low, the depreciation of the dollar without appreciation of Asian currencies would necessarily mean an appreciation of the euro. These would be exactly the circumstances in which Europe would face the kinds of difficulties discussed at the end of the previous section.

The second, perhaps more likely, bad possibility is as follows. Fiscal discipline might not succeed in bringing spending down in the low-saving countries, but, at the same time, consumers in high-saving countries do not greatly expand expenditures. Again we will go back to the global imbalances outcome, but we will do this without requiring very low world interest rates. Under this outcome, growth could be sustained in the medium term, without the kinds of risks to financial markets which would eventuate in the low-interest rate case. Interest rates would be higher, and would have to increasingly rise to prevent expenditure in the US and elsewhere from expanding too rapidly. This outcome could only be sustained if the world was prepared to continue to go on allowing the US to build up more and more debt.

We do not think that this second outcome would be sustainable for more than, say, another half a dozen years. Working against it would be the remorseless process of catching up being undertaken in East Asia - originally in Singapore, Hong Kong, Korea and Thailand, now in China and Vietnam, Indonesia, and Malaysia, and soon in India. This process involves all of these countries encouraging the inflow of FDI, adopting new technologies, becoming yet more competitive, and undercutting yet more of the competitive strength of the US. As this goes on, everyone will come to believe that, in the end, the dollar must fall - so as to enable the US to stop building up further debt, to service its existing debt, and, possibly (see below), to begin to repay some of its debt.

So this second 'strategy' could not lead to a permanent evasion of the 'global imbalances' problem. Nevertheless, the reader might ask, might not the eventual fall in the dollar, when it comes, be gradual? In this case the fiscal indiscipline in the US might merely postpone the required adjustment for another half-dozen years. Might not such a delay even turn out to be desirable?

We are not so hopeful. Our reason is as follows. In Section 3 we described our balance-sheet 
view of why the reversal of the over-extension of credit to the housing sector in the US turned out to be sudden reversal rather than a gradual one, and turned out to involve an overshoot in the price of long-dated, risky, securities. We believe that the reversal of an over-extension of lending to the United States, as a nation, might also turn out to be sudden rather than gradual, and also might turn out to involve an overshoot in the value of the dollar.

The model that one can use to think about this process is that presented four years ago by Blanchard, Giavazzi and Sa (2005). This model is similar to that of Dornbusch (1976), except that it studies exchange-rate determination in a world with imperfect capital mobility. Home and foreign assets are not perfect substitutes, and economic agents have a preference for home assets. In such a setup, something of the kind which we have described above, which causes the dollar to need to depreciate, in order to rectify a current-account deficit, has portfolio valuation implications which must be taken into account. In particular as the dollar falls this will increase the value to US residents of their holdings of foreign assets. And it will reduce, for foreign residents, the value of their holdings of US assets, as valued in their own currency. These (transient) changes in asset values, which occur as the value of the dollar changes, will be beneficial to the US ${ }^{51}$. They will also mean, other things being equal, that the dollar will not fall immediately all the way to its full equilibrium, so as to allow the necessary readjustments of asset portfolios to take place. (See Kuralbeyeva and Vines, 2009.) These portfolio revaluation effects, which come about as a result of a fall in the dollar, which are beneficial to the US, have been much discussed recently. (Gourinchas and Rey, 2005) So far, this model suggests that portfolio balance issues might help to smooth the adjustment process.

However, the way of thinking about balance sheets which we developed in Section 3 suggests that this process might be more difficult than it seems at first sight. In that analysis, the overshoot of financial asset prices happened because of the balance sheet weaknesses of the highly leveraged financial institutions which we identified to be crucial to the financial intermediation process: falling prices of risky, longer term, assets damaged the balance sheets of these institutions and, as a result, pushed up their leverage too much. This caused them to need to sell more of the assets, worsening the pressure on them. It seems possible that some of the foreign portfolio investment in the US which has been holding up the value of the dollar

\footnotetext{
${ }^{51}$ There is a great difference here from what happened to Asian countries as their currencies depreciated strongly during the Asian crisis. Those countries suffered large capital losses, losses which emerged because they had heavy foreign borrowing, denominated in foreign currency. The US is in the opposite position.
} 
in the presence of large current account deficits might be exposed to similar leverage problems. It seems likely that some of this investment in the US has been carried out by highly leveraged financial institutions. We have argued above that correction of the US current account deficit will require a further fall in the dollar. Such a fall in the value of the dollar will expose these institutions to balance sheet losses, which may require them to sell more dollar assets, causing a further fall in the value of the dollar, etc. This argument suggests the possibility of overshoot of the dollar, for exactly the same reasons as the overshoot in the prices of long dated assets discussed in Sections 3.

Furthermore, the remorseless improvement in the global trading position of Asia is likely to be associated with the shift in global portfolio preferences towards Asia, and away from the US. Such a shift will give to rise to further pressures towards over-depreciation of the dollar. When portfolio preferences shift against the dollar, the dollar must fall, not only to bring about the required improvement in the current account, and not only because of the leveragerelated issues discussed above, but also to generate an even larger current-account improvement in the short term, so as to enable portfolio compositions to be rebalanced. (It is only by that means that US residents can build up their holdings of foreign assets, and foreign residents can run down their holdings of US assets.) This will throw into reverse the processes analysed by Caballero et. al .(2008) - who suggested that the US had an ability to have an overvalued exchange rate and run a current-account deficit for an extended period of time. Now a move in the opposite direction may become necessary.

In sum, we believe that the dollar will need to fall in the medium term to restore the trading position of the US. But we also fear that the dollar might overshoot, both for leverage-related reasons, and because of a wish by international asset holders to reduce the proportion of their portfolios held in US assets. This means that we are not optimistic about how this second set of circumstances would lead to a good ending.

\subsection{Building a Robust Global Policy Regime: International Macroeconomic Policy Coordination in the Medium Term}

The global crisis that we have had could have been averted only by a different way of managing macroeconomic policy internationally. A new alternative to the current international non-system is needed, in which there are stronger underlying rules. 
We begin by discussing the circumstances of the advanced G20 countries, and others with floating exchange rates. It is necessary that these nations use three create policy frameworks for the use of three policy instruments (monetary policy, regulatory supervision, and fiscal policy) in the ways which we have described in Sections 5.1 to 5.3. First, interest rates need to continue to manage aggregate demand with the aim of keeping inflation low and, after recovery from the present crisis, keeping unemployment at sustainable levels. Second, countries will need to regulate their financial systems so as to limit speculative risk-taking. Third, countries will need to make the fiscal adjustments that we have described, and will need to do this in a way which is consistent with exchange rate movements, that, over the medium term, will eliminate savings-investment imbalances.

This virtuous trio of three policy frameworks will not be sufficiently self-enforcing, as this decade's experience has so clearly demonstrated. There needs to be a move towards some external enforcement of rules relating to these frameworks.

The experience of the last decade has shown that an inflation targeting regime, in such countries, can be self-enforcing. But even here Posen and Subramanian have suggested that an element of international cooperation may be essential to ensure that there is not free riding in the control of global inflation.

There will clearly need to be international surveillance concerning the other elements of policy, and the IMF needs to play a much stronger role in this process. King (2006a, 2006b), Camdessus (2005), Eichengreen (2009), Bénassy-Quéré and Pisani-Ferry (2009) and many others, have argued for the strengthening of such surveillance.

Macroeconomically, this will require a clearer identification of unsustainable policies with regard to national levels of savings and investment. The IMF's World Economic Outlook is the natural vehicle for this analysis. But so far the Fund has been unable to issue strong enough warnings in such instances. The IMF must be able to warn against unsustainable policies and about the need, say, for the US to save more, and about the inappropriateness of policies in allowing this not to happen. 
Making multilateral surveillance more effective in this way will imply a loss of policy sovereignty. Far more effective global governance of the IMF will be required for this to be possible, and effective. One proposal that has been put forward would place the responsibility for the delivery of improved policies more firmly in the hands of the management of the IMF. At present, the Executive Board of the Fund involves itself in day-to-day reviews of Article IV reports. Stepping back from this activity would enable the global surveillance process to carry out the tasks just described. Evolution in this direction could strengthen the accountability of the Managing Director and his Deputies. In one version of this type of arrangement, all of the Managing Director, the Deputy Managing Directors, and Department Directors, would report on a regular basis to the Board, but Executive Directors would be more removed from many of the day-to-day decisions of the institution, including those about surveillance. (Kenen, 2006, and King, 2006a, 2006b)

It is clear that agreement on surveillance over the policies of advanced countries will be difficult to achieve. But the current system, without effective surveillance, may well lead to is the second set to unsatisfactory outcomes reviewed in Section 5.4. That too would be very costly.

\section{Surveillance of Policy Regimes in which Exchange Rates are pegged}

But this is not enough; changes need to be made in the way in which macroeconomic polices are managed in emerging market economies.

A core requirement of any satisfactory global system is that emerging market economies countries do not save so much that they drive the world towards an outcome in which interest rates are too low, and global imbalances continue. The improved surveillance described above would need to be directed towards this difficulty. A further related issue concerns the fact that many of these countries have, as discussed above, deliberately pursued overly competitive exchange rates. Preventing this might help to ensure that emerging market economies do not pursue macroeconomic policies which adversely affect the rest of the world. For example, an excess of Chinese savings over its investment, without an exchange rate that supported a trade surplus, would have produced a recession in China. As a consequence, perhaps an IMF surveillance process which sought to prevent the maintenance of an undervalued exchange 
rate might hep to induce the required, more expansionary policy response in China.

Such a system would require the IMF to determine the appropriate exchange rate values for countries - 'fundamental equilibrium exchange rates'. The IMF would then be given the power to require countries not to intervene in such a way as to steer their exchange rates away from these fundamental values. It is difficult to specify equilibrium exchange rates. There are a number of ways of doing this which give different answers - the IMF has three different methods (IMF, 2008). As a result this requirement by the Fund could only be activated if a currency was judged to be a significant distance from its fundamental equilibrium level. This would not involve an attempt by the IMF to impose, or fix, exchange rates. Rather it would involve a requirement that countries not intervene in an attempt to maintain exchange rates well away from their fundamental equilibrium values. There would of course be issues of transition; countries with managed exchange rates far from their equilibrium values would be given a period of time during which their managed exchange rate could be brought closer to an equilibrium value.

If such a move is to be possible the international financial system will also need to provide credible insurance to emerging-market countries that avoid setting their exchange rates at depreciated levels, and forego the resulting reserve accumulation. As Portes (2009) has suggested, this could involve central bank swap lines and more ambitious 'reserve pooling' arrangements. But importantly, beyond this, it should also involve a new system of the provision of international reserves for emerging market economies. (See Joshi and Vines, 2010) Such a scheme might be one in which in which the IMF issued SDRs to emerging market countries, and was also given the power to make emergency issues of SDRs to fight crises, making the IMF a 'lender of first resort' (Cohen and Portes, 2006). That might make it unnecessary for countries to seek to run current account surpluses to accumulate foreign reserves for insurance reasons, removing one of the key reasons underlying the current savings investment imbalances in emerging market economies. This would go well beyond the issues of SDRs which were agreed at the April 2009 G20 summit meeting in London. A consequence of such a scheme might be that the US would be less tempted to overspend, since it would lose the "exorbitant privilege" of issuing the world's reserves.

These two reforms to the international monetary system, in the way in which IMF surveillance deals with emerging-market economies, would also imply a loss of sovereignty 
for emerging market economies. They would limit the ability of countries, including emerging market economies, to set their exchange rates in ways which harm the rest of the world. They would also limit the ability of countries that issue reserves, in particular the US, to run excessive deficits. But there is the possibility of making these reforms mutually reinforcing in emerging market economies. It might be possible to link access to SDR financing to countries which were not intervening in such a way as to cause their exchange rates to be greatly undervalued - so as to make the provision of this financial insurance an alternative to running large current account surpluses.

It will be impossible to get agreement on a major role for the IMF in influencing the policies of emerging market economies unless additional changes are made to the governance of the IMF, so that the Fund inspires trust and confidence in these countries. That in turn will need changes in the IMF's distribution of power, and voting structure, so as to reflect the changing realities of the world balance of economic power. The ad hoc provision of increased quota shares in 2006, represented a first step toward realigning voting power in the Fund with emerging markets' growing share of the world economy;, and there was an agreement to move further in this direction at the G20 summit in London in April 2009. Further steps will inevitably require decisions to reduce the shares of others.

All of the proposals for IMF reform reviewed in this section look like a very difficult agenda indeed. Many people argue that they are impossible. By contrast, we think that they can only be avoided at great cost. That statement drives us to the conclusion of this paper.

\section{CONCLUSION}

The world we live in has turned out to be highly volatile and crisis-prone- the great moderation turned out to be a great illusion. Two key features of this world have contributed to this instability.

(i) There was an environment of global savings - investment imbalances which pushed emerging market economies towards export led growth, facilitated by undervalued exchange rates. This was coupled with the use by the US of monetary policy to ensure a steady growth in demand at home and sustain the 'great moderation' - as dictated by an inflation targeting regime. The outcome was one in which world interest rates fell a great deal. 
(ii) There was a financial system in advanced countries with a very high degree of leverage, which, in the presence of low interest rates, engaged in a search for yield which turned out to make the whole international financial system spectacularly fragile.

This combination must not be allowed to happen again. There appear to be two, and only two, ways to prevent this.

The first possibility is that the international monetary system is reformed. The IMF would be given the improved powers of surveillance described in the previous Section, and also given the authority to ensure that global savings-investment imbalances do not cause very large changes in the level of interest rates which are required at the world level. This outcome looks extremely demanding.

The second alternative, if the first fails, is that we must ban the 'Greenspan put'. When circumstances like those in early 2002 present themselves again, with the need for a very large cut in interest rates, which needs to be sustained for an extended period of time, the world must require that the US Federal reserve says NO. The Fed must be able to say 'This is the recession you need to have'. It must be able to say 'We will not cut interest rates to sustain growth ever again in the manner which happened in 2002.' This outcome would, obviously, have great costs.

Back in 1944, when the Bretton Woods system was established, Keynes believed that a system of international cooperation was needed to ensure a well-functioning international monetary system. There was, he said, a need for a set of rules of the game. (Vines, 2003) We believe that Keynes's concerns remain true to this day. Just like then, we need a rules-based international monetary system. The rules to be adopted would - of course - be vastly different from those concerning the management of the pegged-but-adjustable exchange-rate system which was established at Bretton Woods. But nevertheless rules are needed: rules governing the international surveillance of policies by the IMF. And the IMF needs to have the authority to enforce such rules.

This is a demanding agenda. But something like this seems necessary if we are to guard against doing all over again what we have done in the past two years. 


\section{REFERENCES}

Agenor, Richard, Marcus Miller, David Vines, and Axel Weber (1999) The Asian

Financial Crises: Causes, Contagion, and Consequences. Cambridge: Cambridge University Press

Alessandri, P and A.Haldane (2009) "Banking on the State"

http://wwwbankofengland.co.uk/publications/speeches/2009/speech409.pdf/

Allsopp, C. (2009) "Inflation Targeting and Asset Prices", mimeo

Allsopp, C. and Vines, D. (2000) 'The assessment: Macroeconomic Policy, Oxford review of economic policy, 16(4), 1- 33

Allsopp, C. and Vines, D. (2005) 'The macroeconomic role of fiscal policy', Oxford review of economic policy, 21(4), 485- 508

Allsopp, C. and D.Vines (2007) "Fiscal Policy, Labour Markets, and the Difficulties of Intercountry Adjustment Within EMU”, in David Cobham (ed.), The Travails of the Eurozone, Palgrave Macmillan, London

Allsopp C. and D. Vines "Fiscal policy, intercountry adjustment, and the real exchange rate within Europe", forthcoming inEMU@10, European Commission.

Aizenman, J., B.Pinto and A.Radziwill (2004) "Sources for Financing Domestic Capital -is Foreign Saving a Viable Option for Developing Countries” NBER Working Paper no. 10624.

Bean, C. (1998), 'The new UK monetary arrangements: a view from the literature', The Economic Journal, 108, 1795 - 1809 Bean, C. (2009) "The Great Moderation, the Great Panic and the Great Correction”Schumpeter Lecture, European Economics Association, Barcelona, 25 August 2009 (reprinted in Bank of International Settlements Review, vol 101). (http://www.bis.org/review/r090902d.pdf)

Bénassy-Quéré A. and J. Pisani-Ferry (2009) 'Towards a revival of the international monetary discussion?' Paper prepared for the AEEF Conference, Kiel Institution the World Economy, July.

Bernanke, B.S. (2004) 'Great Moderation', speech given at the meetings of the Eastern Economic Association, Washington, DC, February 20, 2004. 
Bernanke, B. S., (2005), 'The global saving glut and the US current account deficit', Sandridge Lecture, Virginia Association of Economics, Richmond, Virginia, 10 March

Bernanke, B.S. (2009) “The Crisis and the Policy Response” Stamp Lecture, LSE, London 13 Jan, 2009. (http://www.federalreserve.gov/newsevents/speech/bernanke20090113a.htm)

Bernanke, B.S., M.Gertler, and S.Gilchrist (1999) “The financial accelerator in a quantitative business cycle framework" in Taylor, J.B. and M. Woodford (eds.) Handbook of Macroeconomics, volume 1, chapter 21, pages 1341-1393, Amsterdam: Elsevier.

Besley, T et al (2010) 'UK economy cries out for credible rescue plan', Sunday Times, February 14

Blanchard, O (2008) “The State of Macro” NBER Working Paper No.14259

Blanchard, O, G. Dell'Ariccia and P.Mauro (2010) "Rethinking Macroeconomic Policy” IMF Staff Position Note, February, SPN/10/03.

Blanchard, O. and G. Milesi Ferretti (2009) “Global Imbalances: In Midstream” IMF Staff Position Note, December, SPN/09/29

Blanchard, O., F.Giavazzi and F.Sa (2005) "International Invetors, the US Current Account and the Dollar" Brookings Papers on Economic Activity ivol 36 pp 1-66.

Caballero, R., E. Farhi, and P.-O. Gourinchas (2008), 'An equilibrium model of 'global imbalances' and low interest rates', American Economic Review.

Camdessus, M. (2005) 'International Financial Institutions: Dealing with New Global Challenges' Per Jacobsen Lecture, Washington DC, 2005.

Carlin, W. and D. Soskice (2005) "The 3-Equation New Keynesian Model - A Graphical Exposition", Contributions to Macroeconomics Volume 5, Issue 1,Article 13

Christiano, L., M.Eichenbaum and C.Evans (2005) "Nominal Rigidities and the Dynamic Effects of a Shock to Monetary Policy” Journal of Political Economy, 113 (1), 1- 45.

Christiano, L., M.Eichenbaum and S.Rebelo (2009) "When is the Government Spending Multiplier Large" mimeo Northwestern University http://faculty.wcas.northwestern.edu/ yona/research/Multiplier-version12.pdf

Chung, D. and B. Eichengreen (2003) Korean Economy beyond the Crisis Cheltenham: Edward Elgar

Clarida, R., Gali, J. and Gertler, M. (1999), 'The Science of Monetary Policy: A new Keynesian perspective', Journal of Economic Review, 37(4), 1661 - 1707. 
Cohen, D. and R. Portes (2006), 'A lender of first resort', CEPR Discussion Paper no. 4615, 2004. Revised version as IMF Working Paper WP/06/66, March 2006.

Congdon, T (2009) "Keep the money flowing to stave off deflation" Financial Times, 8 July.

Corbett, J. and D. Vines, (1999a) 'Asian Currency and Financial Crises: Lessons from Vulnerability, Crisis, and Collapse', World Economy, 22 (2), March, pp. 155-77.

Corbett, J. and D. Vines (1999b) "The Asian Financial Crisis: Lessons from the Collapse of Financial Systems, Currencies, and Macroeconomic Policy”. in Agenor, Miller, Weber and Vines (1999).

Corbett J., G. Irwin and D. Vines, (1999), 'From Asian Miracle to Asian Crisis: Why Vulnerability, Why Collapse?', in D. Gruen and L. Gower (eds), Capital Flows and the International Financial System. Sydney: Reserve Bank of Australia, reprinted in Irwin and Vines, 2001.

Dooley, M., D. Folkerts-Landau, and P. Garber (2004a), 'The Revised Bretton Woods System,' International Journal of Finance and Economics, 307-313.

Dooley, M. D. Folkerts-Landau, and P. Garber (2004b) "Direct Investment, Rising Real Wages and the Absorption of Excess Labor in the Periphery," NBER Working Paper no. 10626 .

Dooley, M., D Folkerts-Landau, and P.Garber (2005) "Savings Gluts and Interest Rates: The Missing Link to Europe" NBER Working Paper no 11520.

Dornbusch, R. (1976) “Expectations and Exchange Rate Dynamics” Journal of Political Economy vol 84 pp 1161-76.

Eichengreen, B. (2004) The Dollar and the New Bretton Woods System, , Thornton Lecture, Cass Business School, London

Eichengreen, B (2009) “What is the IMF’s Mission Project Syndicate, 1 July 2009. http://www.project-syndicate.org/series/78/description

Eichengreen, B. and Y. C. Park (2006) Global Imbalances: Implications for Emerging Asia and Latin America1 in Jan Joost Teunissen and Age Akerman (eds), Global Imbalances and the U.S. Debt Problem, The Hague: Fondad, pp.14-44.

Ferguson, N. (2008) The Ascent of Money London, Penguin.

Financial Times (2010) “Obama Hammers Wall St Banks” Financial Times, 21 January.

Freedman, C., M.Kimhof, D.Laxton and J.Lee 92009) “The case for global fiscal stimulus" IMF Staff Position Note (09/03).

Garnaut, R. and D.Llewellyn-Smith (2009) The Great Crash of 20088 Melbourne: Melbourne University Press 
Gertler, M., and Karadi, P. (2009), ‘A model of unconventional monetary policy’, mimeo, NYU, April.

Gertler, M. and N. Kiyotaki, (2009), 'Financial Intermediation and Credit Policy in Business Cycle Analysis', in Friedman, B. and Woodford, M. (eds), Handbook of Monetary Economics, Volume 3, North Holland.

Gourinchas, P. and H. Rey (2005) “International Financial Adjustment”, NBER Working Paper, No. W11155, February

Gilchrist, S., A. Ortiz and E. Zakraj;sek (2009) “Credit Risk and the Macroeconomy: Evidence from an Estimated DSGE Model" Paper prepared for the FRB/JMCB conference "Financial Markets and Monetary Policy," held at the Federal Reserve Board, Washington D.C., June 4-5.

Haldane, A. G. (2009), 'Rethinking the financial network', Speech at Financial Student Association, Amsterdam, April

Hall, R.E. (2009) "By how much does GDP rise if the government buys more output" NBER Working Paper No.15496.

House, B, D. Vines and M. Corden (2008) 'The International Monetary Fund', New Palgrave Dictionary of Economics, Revised Edition. London: Macmillan

Hong, H. (2009) 'I.Q and the Destiny of Financial Markets', powerpoint slides of a talk presented to a Conference on 'The Crash of the Financial System: Bad Luck or Bad Structure' held at University of Technology Sydney, $28^{\text {th }}$ to $30^{\text {th }}$ October.

IMF (2008) Exchange Rate Assessments: CGER Methodologies IMF Occasional Paper No 261.

IMF(2009) World Economic Outlook (October) Washington DC, IMF.

Irwin, G. and D. Vines (2001) Financial Market Integration and International Capital Flows. Cheltenham: Edward Elgar

Issing, O (2010) “Europe Cannot Afford to Rescue Greece” Financial Times, 15 Feb 2010. Joshi, V and D.Vines (2008) 'A New Bretton Woods should curb Boom and Bust', http://www.voxeu.org/index.php?q=node/2544

Kapadia, S. (2005), 'Inflation Target Expectations and Optimal Monetary Policy’Oxford University Department of Oxford Working Paper No. 227

Kenen, P. (2006) 'Comments on the Address of the Managing Director of the IMF to the Petersen Institute for International Economics', April 20

King, M. (2006a), 'Reform of the International Monetary Fund', speech given to the Indian Council for Research on International Economic Relations', New Delhi, February 20 
2006, "http://www.bankofengland.co.uk

King, M. (2006b) 'Through the Looking Glass: Reform of the International Institutions'. Inaugural International Distinguished Lecture, Melbourne Centre for Financial Studies, Australia, 21 December

King,M. (2009a) Mansion House Speech, June.

http://wwwbankofengland.co.uk/publications/speeches/2009/speech394.pdf

King (2009b) Speech to Scottish Business Organisations. October.

http://wwwbankofengland.co.uk/publications/speeches/2009/speech406.pdf

Kirsanova, T., Stehn, J. and Vines, D. (2005), 'The interactions between fiscal policy and monetary policy', Oxford Review of Economic Policy, 21(4), 532 - 564.

Kiyotaki, N., and J. Moore, (1997), 'Credit cycles', Journal of Political Economy, vol. 105(2), pp.211-248.

Krugman, P (2008) 'The International Financial Multiplier', available at _www.princeton.edu/ p pkrugman/finmult.pdf

Krugman, P. (2009) 'How did economists get it so wrong?'New York Times, 6 September.

Kuralbeyeva, K and D.Vines (2009) "The process by which the Dollar will fall: the effect of forward-looking consumers" CEPR Discussion Paper No.7325.

Layard, R and others (2010) “Sharp shocks now would be dangerous" Letter to Financial Times, 18 February.

Luk, P. and D.Vines (2010a) 'Putting Goldman Sachs into a Ramsey Model' CEPR Discussion Paper (forthcoming)

Luk,P. and D. Vines (20010b) 'On the Mechanisms of International Cooperation', mimeo, University of Oxford.

May, R., S.Levin and G.Sugihara (2007) “Complex Systems: Ecology for Bankers” Nature, vol 451, pp 893-895.

May, R. (2010) “Complexity in Banking Systems” James Martin School for the $21^{\text {st }}$ Century, University of Oxford http://www.21school.ox.ac.uk/news_and_events/events\%20/2010H_seminar_Series.cfm

McKibbin, W. (1988) “The Economics of International Policy Coordination” Economic Record, vol 64, pp $242-253$

McKibbin and Vines (2003) "Changes in Equity Risk Perceptions: Global Consequences and Policy Responses” Australian National University, Department of Economics Departmental Working Paper 2003-15.Departmental Working Paper 2003-15. 
Mendoza, E., et al. (2007), 'Financial integration, financial deepness, and global imbalances', CEPR Discussion Paper no. 6149.

Miller, M and J. Stiglitz. (2009) 'Leverage and Asset Bubbles: Averting Armageddon with Chapter 11. CEPR Discussion Paper 7469.

Obstfeld, M. and Rogoff, K. (2002), 'Global Implications of Self-Orientated Macroeconomic Policies?', Quarterly Journal of Economics, 117, 503 - 535

Obstfeld, M. and K. Rogoff (2007) “The Unsustainable US Current Account Position Revisited” in R.Clarida (ed) "G7 Current Account Balances: Sustainability and Adjustment" NBER Books, Chicago University Press.

Obstfeld M. and K. Rogoff (2009) "Global Imbalances and the Financial Crisis: Products of Common Causes” Federal Reserve Bank of San Francisco Asia Economic Policy Conference, Santa Barbara, CA, October 18-20, 2009

Portes, R. (2009) 'Global Imbalances', mimeo, London Business School, February

Prasad, E. (2009) "Rebalancing Growth in Asia" NBER Working Paper No. 15169.

Shin, H. (2008) Risk and Liquidity, 2008 Clarendon Lectures in Finance, University of Oxford. (forthcoming, Oxford University Press) http://www.princeton.edu/ hsshin/ClarendonLectures.htm

Skidelsky, R. (2000) John Maynard Keynes: Fighting for Britain, 1937-1946 London: Macmillan.

Smets, F. and Wouters, R. (2003), 'An estimated dynamic stochastic general equilibrium model of the euro area', Journal of the European Economic Association, 1(5), 1123 1175 .

Solow, R. (1956) “A Contribution to the Theory of Economic Growth.” Quarterly Journal of Economics, 70 (1) 65-94

Spilimbergo, A., S.Symansky and M.Schindler (2009) "Fiscal Multipliers" IMF Staff Position Note SPN/09/11.

Stolz, S, M. And M.Wedow (2009) "Extraordinary Measures in Extraordinary Times: Bank Rescue Operations in Europe and the US" (mimeo, ECB).

Taylor, J (2008) 'The Financial Crisis and the Policy Responses: An Empirical Analysis of What Went Wrong’ http://www.stanford.edu/ johntayl/

Truman, E. (2009) 'Global Imbalances and the International Monetary System', comment presented at an ICRIER-CEPII-BRUEGEL Conference on International Cooperation in Times of Global Crisis: Views from G20 Countries, New Delhi, 14 \& 15 September 2009. 
Turner, A (2009) "The Financial Crisis and the Future of Financial Regulation" The Economist City Lecture, January 2009.

Vines, D., (2003), 'John Maynard Keynes 1937-1946: the Creation of International Macroeconomics', Economic Journal, 113 (448), F338-61.

Vines, D. (2008) James Meade, New Palgrave Dictionary of Economics, Revised Edition. London: Macmillan.

Vines, D. (2009) ' The Financial Crisis, Global Imbalances, and the International Monetary System', presented at an ICRIER-CEPII-BRUEGEL Conference on International Cooperation in Times of Global Crisis: Views from G20 Countries, New Delhi, 14 \& 15 September 2009. http://www.bruegel.org/nc/publications/events/new-delhiconference.html

Vines, D and P. Warr (2003), 'Thailand's investment-driven boom and crisis', Oxford Economic Papers, 55(3), 440 - 446.

Yu Yongding (2009) 'China’s Policy Responses to Global Economic Crisis and its Perspective on the Reform of International monetary system' Prepared for the AEEF Conference, Kiel Institution the World Economy, July

Wadhwani, S. (2008) "Should Monetary Policy Respond to Asset Price Bubbles: Revisiting the Debate" National Institute Economic Review, vol 206.

Wei, Shang-Jin and Xiaobo Zhang (2009), "The Competitive Saving Motive: Evidence from

Rising Sex Ratios and Savings Rates in China”, NBER Working Paper 15093.

White, W. (2009) “' 'Should Monetary Policy 'Lean or Clean'?”Globalization and Monetary Policy Institute Working Paper 34 (Dallas,Texas: Federal Reserve Bank of Dallas). Wicksell, K (1898) Interest and Prices: A Study of the Cause Regulating the Value of Money" (English language translation by R.F.Kahn (1936), London, MacMillan.

Woodford, (2003), Interest and Prices, New York, Princeton University Press.

Wolf, M (2008) Fixing Global Finance. Yale University Press

Wolf, M.(2010a) “Europe Needs German Consumers” Financial Times, 9 February

Wolf, M (2010b) “The Eurozone Crisis is now a Nightmare for Germany", Financial Times, 10 March. 